\title{
Fulfilling the promise of the materials genome initiative with high-throughput experimental methodologies
}

\author{
M. L. Green, ${ }^{1, a)}$ C. L. Choi, ${ }^{2}$ J. R. Hattrick-Simpers, ${ }^{1}$ A. M. Joshi, ${ }^{3}$ I. Takeuchi, ${ }^{4}$ \\ S. C. Barron, ${ }^{5}$ E. Campo, ${ }^{6}$ T. Chiang, ${ }^{7}$ S. Empedocles, ${ }^{8}$ J. M. Gregoire, ${ }^{9}$ A. G. Kusne,${ }^{1}$ \\ J. Martin, ${ }^{1}$ A. Mehta, ${ }^{10}$ K. Persson, ${ }^{11}$ Z. Trautt, ${ }^{1}$ J. Van Duren, ${ }^{7}$ and A. Zakutayev ${ }^{12}$ \\ ${ }^{1}$ National Institute of Standards and Technology (NIST), Gaithersburg, Maryland 20899, USA \\ ${ }^{2}$ Google, Mountain View, California 94043, USA \\ ${ }^{3}$ Applied Materials, Inc., Santa Clara, California 95054, USA \\ ${ }^{4}$ Department of Materials Science and Engineering, University of Maryland, College Park, Maryland 20742, USA \\ ${ }^{5}$ Charles Stark Draper Laboratory, Cambridge, Massachusetts 02139, USA \\ ${ }^{6}$ School of Electronic Engineering, Bangor University, Gwynedd LL57 2DG, United Kingdom \\ ${ }^{7}$ Intermolecular, Inc., San Jose, California 95134, USA \\ ${ }^{8}$ Clark Street Associates, Palo Alto, California 94301, USA \\ ${ }^{9}$ Joint Center for Artificial Photosynthesis (JCAP), Pasadena, California 91125, USA \\ ${ }^{10}$ SLAC National Accelerator Laboratory, Menlo Park, California 94025, USA \\ ${ }^{11}$ Lawrence Berkeley National Laboratory, Berkeley, California 94720, USA \\ ${ }^{12}$ National Renewable Energy Laboratory (NREL), Golden, Colorado 80401, USA
}

(Received 12 September 2016; accepted 9 February 2017; published online 28 March 2017)

\begin{abstract}
The Materials Genome Initiative, a national effort to introduce new materials into the market faster and at lower cost, has made significant progress in computational simulation and modeling of materials. To build on this progress, a large amount of experimental data for validating these models, and informing more sophisticated ones, will be required. High-throughput experimentation generates large volumes of experimental data using combinatorial materials synthesis and rapid measurement techniques, making it an ideal experimental complement to bring the Materials Genome Initiative vision to fruition. This paper reviews the state-of-the-art results, opportunities, and challenges in high-throughput experimentation for materials design. A major conclusion is that an effort to deploy a federated network of high-throughput experimental (synthesis and characterization) tools, which are integrated with a modern materials data infrastructure, is needed. (c) 2017 Author(s). All article content, except where otherwise noted, is licensed under a Creative Commons Attribution (CC BY) license (http://creativecommons.org/licenses/by/4.0/).
\end{abstract}

[http://dx.doi.org/10.1063/1.4977487]

\section{INTRODUCTION}

Materials are technology enablers, and the discovery and commercialization of advanced materials is crucial to solving major challenges in technological innovation, economic growth, and the environment. In 2011, President Obama announced the Materials Genome Initiative (MGI), ${ }^{1}$ a national effort to introduce new materials into commerce more quickly (by a factor of 2, i.e., from about 10-20 years to about 5-10 years) and at a lower cost. The MGI approach requires contributions in three critical areas: computational tools, experimental tools, and digital data. Since its inception, the MGI has made significant progress in predicting the structure and properties of new functional materials through computational simulation and modeling. To build on this progress, experimental data for validating these models, and informing more sophisticated ones, will be required. Highthroughput experimental (HTE) methodologies ${ }^{2-10}$ typically

${ }^{\text {a)} E-m a i l: ~ m a r t i n . g r e e n @ n i s t . g o v ~}$ employ combinatorial materials science techniques wherein materials "libraries" are synthesized and characterized to rapidly determine structural, physical, and chemical properties. Due to their ability to rapidly establish relationships between composition, structure, and functional properties, HTE methodologies are uniquely suited as the experimental complement of computational simulation and modeling.

Today's global challenges, e.g., advanced manufacturing, dependence on critical raw materials, and climate change, underscore the urgent need for novel materials solutions (Table I). Advances in HTE methodologies have been successfully demonstrated in every class of technologically important materials, and it has been demonstrated that HTE can lead to the discovery and deployment of new materials at unprecedented speed and low cost. ${ }^{4,5,7,9,11-15}$ However, according to the results of a recent HTE workshop, ${ }^{16}$ full realization of the MGI vision will require the integration of experiment, computation, and theory, open access to high quality digital data and materials informatics tools, and an educated workforce. 
TABLE I. Timely discovery and commercialization of advanced materials technologies are crucial to addressing major national and global challenges.

\begin{tabular}{|c|c|}
\hline Major challenges & Materials solution \\
\hline \multirow[t]{5}{*}{ National security } & $\begin{array}{l}\text { Low-weight, high-strength } \\
\text { transportation materials }\end{array}$ \\
\hline & Extended life batteries \\
\hline & Radiation detecting materials \\
\hline & Solar powered military equipment \\
\hline & High sensitivity magnetometer materials \\
\hline \multirow[t]{2}{*}{$\begin{array}{l}\text { Dependence on } \\
\text { critical raw materials }\end{array}$} & $\begin{array}{l}\text { Reliably available catalysts } \\
\text { and permanent magnets }\end{array}$ \\
\hline & High-temperature turbines \\
\hline \multirow[t]{6}{*}{ Climate change } & High-efficiency, low-cost solar cells \\
\hline & Strong, increased-efficiency wind turbines \\
\hline & $\begin{array}{l}\text { Materials for } \mathrm{CO}_{2} \text { absorption, } \\
\text { capture, and chemical conversion }\end{array}$ \\
\hline & Fuel cell and solar fuels catalysts \\
\hline & $\begin{array}{l}\text { Materials for } \mathrm{CH}_{4} \text { storage, } \\
\text { conversion, and utilization }\end{array}$ \\
\hline & Chemical and biological sensors \\
\hline \multirow[t]{2}{*}{ Electronics demand } & Smaller, higher-performance transistors \\
\hline & Atomic control over device interfaces \\
\hline \multirow[t]{2}{*}{ Economic growth } & $\begin{array}{l}\text { Cost-effective materials for increased } \\
\text { U.S. production and manufacturing }\end{array}$ \\
\hline & New hardware and materials-based technologies \\
\hline
\end{tabular}

This paper reviews the opportunities and challenges facing the use of HTE for materials innovation. Advances in new materials for the energy, electronics, chemical, aerospace, and defense sectors will provide technology solutions and drive economic growth. Ultimately, a strong and widespread MGI community will establish a "materials superhighway" to address the urgent, high impact, and materialsconstrained challenges facing the nation.

\section{SUMMARY OF THIS PAPER'S CONCLUSIONS AND RECOMMENDATIONS}

Major conclusions to be discussed in detail in this paper are as follows:

- Critical technologies such as energy production and utilization, microelectronics, and catalysis await immediate materials solutions through the discovery and development of higher performance photovoltaic (PV), thermoelectric, energy storage, fuel cell, semiconductor, and catalytic materials.

- Existing United States Government-funded MGI-related materials design programs (Table II), while producing excellent research, lack optimized coordination, resulting in underdeveloped opportunities and capabilities in data collection, curation, and analysis; although most elements of the required MGI infrastructure exist, distributed over government (as well as academic and industrial) laboratories, there are few mechanisms for interaction.

- Widespread utilization of HTE methodologies is required to inform and validate computational MGI efforts.

- HTE methodologies are uniquely suited to rapidly generate the large volumes of high quality materials data required to populate materials properties databases.
- Standards for library synthesis, characterization, and data curation (e.g., library architectures, data formats, and informatics) are crucial for effective and widespread use of HTE investments.

Key recommendations are as follows:

- Enable broad access to HTE methodologies and data.

- Establish collaborations that accelerate commercialization in critical advanced materials arenas including electronic materials, catalysts, and energy-related materials.

- Establish HTE facilities, physical or virtual, centralized or distributed, where researchers can implement a total MGI approach for critical and enabling classes of materials.

- Develop new library design and characterization techniques that extend the scope of HTE methodologies beyond just composition space:

- Include measurement and characterization of surfaces and interface properties (e.g., transport, electronic, phonon, and grain boundary effects).

- Focus efforts on specific properties relevant to end-use applications of new materials, e.g., reliability of integrated device structures.

- Create libraries that include variations in processing parameters.

\section{OPPORTUNITIES}

\section{Energy generation: Photovoltaics}

Immediate materials solutions are needed in the area of energy production, in particular, photovoltaics (PV). The PV industry has undergone tremendous growth and restructuring over the past decade and is currently dominated by Si-based polycrystalline or single-crystal wafer technologies. A few other thin film materials systems, such as CdTe and $\mathrm{Cu}(\mathrm{In}, \mathrm{Ga}) \mathrm{Se}_{2}$ (CIGS), are also being manufactured at large scale. In addition, the emergence of hybrid organic-inorganic perovskite PV absorber materials ${ }^{30}$ is revolutionizing PV research and development. However, more progress is needed in increasing the efficiency, reducing the cost, and improving the reliability of the established and emerging PV technologies, all within the boundary conditions of using scalable manufacturing processes and non-critical chemical elements. This requires material innovation in light absorbers, electrical contacts, and other layers and components of PV cells and modules, all applications that can benefit from the HTE approach.

A major challenge for HTE PV research is that solar cells are very sensitive to processing conditions and materials interactions; this is one example of the need to extend HTE research beyond composition space. Screening of processing conditions is important because process-dependent defects and microstructure control the lifetime of photoexcited charge carriers, which limits the performance of solar absorbers. HTE screening of materials interactions (in addition to individual materials) is also important because solar cell performance depends on band offsets and recombination velocities at the interfaces between PV absorbers and contacts. Hence, an HTE approach to measure the effects of a variety of processing conditions and materials interactions 
TABLE II. Selected list of current United States Government-funded materials design programs

\begin{tabular}{|c|c|c|c|}
\hline Name & Lead institution(s) & Mission & Government support \\
\hline $\begin{array}{l}\text { Center for the Computational Design } \\
\text { of Functional Layered Materials } \\
(\mathrm{CCDM})^{17}\end{array}$ & $\begin{array}{l}\text { Temple University } \\
\text { Princeton University } \\
\text { Duke University } \\
\text { Rice University } \\
\text { North Carolina State University } \\
\text { Brookhaven National Laboratory } \\
\text { University of Pennsylvania } \\
\text { Drexel University } \\
\text { Northeastern University }\end{array}$ & $\begin{array}{l}\text { Develop, apply, and } \\
\text { validate theoretical methods } \\
\text { to calculate the electronic } \\
\text { structure of materials }\end{array}$ & Department of Energy \\
\hline $\begin{array}{l}\text { Center for Computational Materials } \\
\text { Design (CCMD) }\end{array}$ & $\begin{array}{l}\text { Penn State University } \\
\text { Georgia Institute of Technology } \\
\text { Boeing } \\
\text { Carpenter } \\
\text { Gulfstream } \\
\text { Medtronic } \\
\text { United States Army }\end{array}$ & $\begin{array}{l}\text { Educate next generation } \\
\text { of scientists and engineers } \\
\text { with industrially relevant } \\
\text { perspective to contribute to } \\
\text { materials design }\end{array}$ & National Science Foundation \\
\hline $\begin{array}{l}\text { Center of Excellence on Integrated } \\
\text { Materials Modeling (CEIMM) }\end{array}$ & $\begin{array}{l}\text { The Johns Hopkins University } \\
\text { University of Illinois } \\
\text { (Urbana-Champagne) } \\
\text { University of California } \\
\text { (Santa Barbara) } \\
\text { Wright-Patterson Air Force Base } \\
\text { Pratt and Whitney } \\
\text { GE Aviation } \\
\text { Lockheed-Martin } \\
\text { Boeing } \\
\text { Simpleware } \\
\text { Scientific Forming Technologies }\end{array}$ & $\begin{array}{l}\text { Collaborative, multidisciplinary } \\
\text { research and educational program } \\
\text { to foster foundational advances } \\
\text { in computational and experimental } \\
\text { methodologies }\end{array}$ & $\begin{array}{l}\text { Department of Defense } \\
\text { (Air Force Research } \\
\text { Laboratory) }\end{array}$ \\
\hline $\begin{array}{l}\text { Center for Hierarchical Materials } \\
\text { Design }(\mathrm{CHiMaD})^{20}\end{array}$ & $\begin{array}{l}\text { Northwestern University } \\
\text { University of Chicago } \\
\text { Argonne National Laboratory } \\
\text { Questek Innovations } \\
\text { ASM International } \\
\text { Fayetteville State University }\end{array}$ & $\begin{array}{l}\text { Accelerate materials discovery } \\
\text { and commercialization by design } \\
\text { and development } \\
\text { of hierarchical methods } \\
\text { and materials }\end{array}$ & $\begin{array}{l}\text { Department of Commerce } \\
\text { (National Institute of } \\
\text { Standards and Technology) }\end{array}$ \\
\hline $\begin{array}{l}\text { Center for Materials in Extreme Dynamic } \\
\text { Environments (CMEDE) })^{21}\end{array}$ & $\begin{array}{l}\text { California Institute of Technology } \\
\text { University of Delaware } \\
\text { Drexel University } \\
\text { The Johns Hopkins University } \\
\text { Morgan State University } \\
\text { New Mexico Institute of Mining and } \\
\text { Technology } \\
\text { North Carolina Agricultural and } \\
\text { Technical State University } \\
\text { Purdue University } \\
\text { Rutgers University } \\
\text { University of North Carolina } \\
\text { (Charlotte) } \\
\text { University of Texas (San Antonio) } \\
\text { Washington State University }\end{array}$ & $\begin{array}{l}\text { To design, optimize, and fabricate } \\
\text { material systems exhibiting } \\
\text { revolutionary performance in } \\
\text { extreme dynamic environments }\end{array}$ & $\begin{array}{l}\text { Department of Defense } \\
\text { (Army Research Laboratory) }\end{array}$ \\
\hline $\begin{array}{l}\text { Center for Next Generation of Materials } \\
\text { by Design: Incorporating Metastability } \\
(\text { CNGMD })^{22}\end{array}$ & $\begin{array}{l}\text { National Renewable Energy Laboratory } \\
\text { University of California (Berkeley) } \\
\text { Colorado School of Mines } \\
\text { Harvard University } \\
\text { Lawrence Berkeley National Laboratory } \\
\text { Massachusetts Institute of Technology } \\
\text { Oregon State University } \\
\text { SLAC National Accelerator Laboratory }\end{array}$ & $\begin{array}{l}\text { Transform the discovery of } \\
\text { functional energy materials } \\
\text { through multiple-property } \\
\text { searching, incorporation } \\
\text { of metastable materials into } \\
\text { predictive design, and development } \\
\text { of theory to guide } \\
\text { materials synthesis. }\end{array}$ & Department of Energy \\
\hline $\begin{array}{l}\text { Center for Theoretical and } \\
\text { Computational } \\
\text { Materials Science (CTCMS) }{ }^{23}\end{array}$ & $\begin{array}{l}\text { National Institute of Standards } \\
\text { and Technology }\end{array}$ & $\begin{array}{l}\text { Establish materials models in } \\
\text { support of materials measurement } \\
\text { and data }\end{array}$ & Department of Commerce \\
\hline
\end{tabular}


TABLE II. (Continued.)

\begin{tabular}{|c|c|c|c|}
\hline Name & Lead institution(s) & Mission & Government support \\
\hline $\begin{array}{l}\text { Exascale Co-design Center for } \\
\text { Materials in Extreme Environments } \\
(\text { ExMatEx })^{24}\end{array}$ & $\begin{array}{l}\text { Los Alamos National Laboratory } \\
\text { Lawrence Livermore National } \\
\text { Laboratory } \\
\text { Oak Ridge National Laboratory } \\
\text { Sandia National Laboratory } \\
\text { Stanford University } \\
\text { California Institute of Technology }\end{array}$ & $\begin{array}{l}\text { Establish interrelationship } \\
\text { among algorithms, } \\
\text { software, and hardware } \\
\text { required to develop } \\
\text { a simulation framework } \\
\text { for modeling materials } \\
\text { under extreme environments }\end{array}$ & Department of Energy \\
\hline $\begin{array}{l}\text { Inorganometallic Catalyst } \\
\text { Design Center (ICDC) }\end{array}$ & $\begin{array}{l}\text { University of Minnesota } \\
\text { Argonne National Laboratory } \\
\text { Clemson University } \\
\text { Dow } \\
\text { Northwestern University } \\
\text { NuMat Technologies } \\
\text { Pacific Northwest National } \\
\text { Laboratory } \\
\text { University of California (Davis) } \\
\text { University of Washington }\end{array}$ & $\begin{array}{l}\text { Computationally guided } \\
\text { discovery of a new class of } \\
\text { energy-science-relevant } \\
\text { catalytic materials and the underlying } \\
\text { structure-function relationships }\end{array}$ & Department of Energy \\
\hline $\begin{array}{l}\text { Joint Center for Artificial } \\
\text { Photosynthesis (JCAP) }\end{array}$ & $\begin{array}{l}\text { California Institute of Technology } \\
\text { Lawrence Berkeley National Laboratory } \\
\text { University of California } \\
\text { (Irvine and San Diego) } \\
\text { Stanford University } \\
\text { SLAC National Accelerator Laboratory }\end{array}$ & $\begin{array}{l}\text { Create the scientific foundation for } \\
\text { a scalable technology } \\
\text { that converts carbon dioxide, } \\
\text { water, and sunlight } \\
\text { into renewable transportation fuels }\end{array}$ & Department of Energy \\
\hline $\begin{array}{l}\text { Nanoporous Materials } \\
\text { Genome Center (NMGC) }{ }^{27}\end{array}$ & $\begin{array}{l}\text { University of Minnesota } \\
\text { University of California (Berkeley) } \\
\text { Rice University } \\
\text { Northwestern University } \\
\text { Georgia Institute of Technology } \\
\text { Cornell University } \\
\text { Washington State University } \\
\text { Lawrence Berkeley } \\
\text { National Laboratory }\end{array}$ & $\begin{array}{l}\text { Discover and explore } \\
\text { microporous } \\
\text { and mesoporous materials }\end{array}$ & $\begin{array}{l}\text { Department of Energy } \\
\text { (Basic Energy Sciences) }\end{array}$ \\
\hline $\begin{array}{l}\text { Predictive Integrated Structural } \\
\text { Materials Science (PRISMS) }\end{array}$ & University of Michigan & $\begin{array}{l}\text { Establish a unique scientific } \\
\text { platform to accelerate predictive } \\
\text { materials science for structural metals }\end{array}$ & Department of Energy \\
\hline $\begin{array}{l}\text { Rational Design of Advanced } \\
\text { Polymeric Capacitor Films }{ }^{29}\end{array}$ & $\begin{array}{l}\text { University of Connecticut } \\
\text { University of Akron } \\
\text { Columbia University } \\
\text { Pennsylvania State } \\
\text { University } \\
\text { Rensselaer Polytechnic Institute }\end{array}$ & $\begin{array}{l}\text { Design of new classes of polymeric } \\
\text { materials with high dielectric constant } \\
\text { and high breakdown strength } \\
\text { for application in high voltage and } \\
\text { high energy density capacitor } \\
\text { technologies }\end{array}$ & $\begin{array}{l}\text { Department of Defense } \\
\text { (Office of Naval Research) }\end{array}$ \\
\hline
\end{tabular}

is needed. The same argument applies to other alternative energy technologies where highly integrated, microstructuredependent multilayer devices are used, such as solid state batteries $^{31}$ or solid oxide fuel cells. ${ }^{32}$

Recently, progress has been made in addressing the HTE challenges of PV materials processing. For example, HTE screening of substrate temperature and target-substrate distance has been demonstrated for $\mathrm{Cu}_{3} \mathrm{~N}^{33}$ and $\mathrm{Cu}_{2} \mathrm{O}^{34,35}$ absorbers, as well as $\mathrm{ZnO}^{36}$ and $\mathrm{In}_{2} \mathrm{~S}_{3}{ }^{37}$ contacts. Methods for screening processing parameters rely on intentional continuous or discrete temperature gradients across the substrates during library synthesis, ${ }^{38,39}$ as shown in Fig. 1(a). HTE screening has also addressed materials interactions through the fabrication of combinatorial PV device libraries with intentional composition and thickness gradients in one layer (e.g., absorber or contact) of a multi-layer stack (Fig. 1(b)).
Such HTE research has been performed for a range of solar cell absorber materials, from quite mature (e.g., $\mathrm{Cu}(\mathrm{In}, \mathrm{Ga}) \mathrm{Se}_{2},{ }^{40,41}$ to emerging (e.g., $\mathrm{Cu}_{2} \mathrm{ZnSnS}_{4}{ }^{42}$ and $\mathrm{CuSbSe}_{2}{ }^{43}$ ), to very novel (e.g., $\mathrm{Co}_{3} \mathrm{O}_{4}{ }^{44}$ and $\mathrm{Cu}_{2} \mathrm{O}^{45}$ ). For some of these absorbers, the PV efficiency was correlated with quasi-Fermi level splitting determined from photoluminescence mapping. ${ }^{42}$ However, more work is needed on spatially resolved characterization of other photo-excited charge carrier properties, such as bulk minority carrier lifetime or surface recombination velocity.

\section{Energy conversion: Thermoelectrics}

The recovery of waste heat using thermoelectric devices represents an enormous opportunity for materials innovation to impact energy utilization. In the United States, the 
(a)
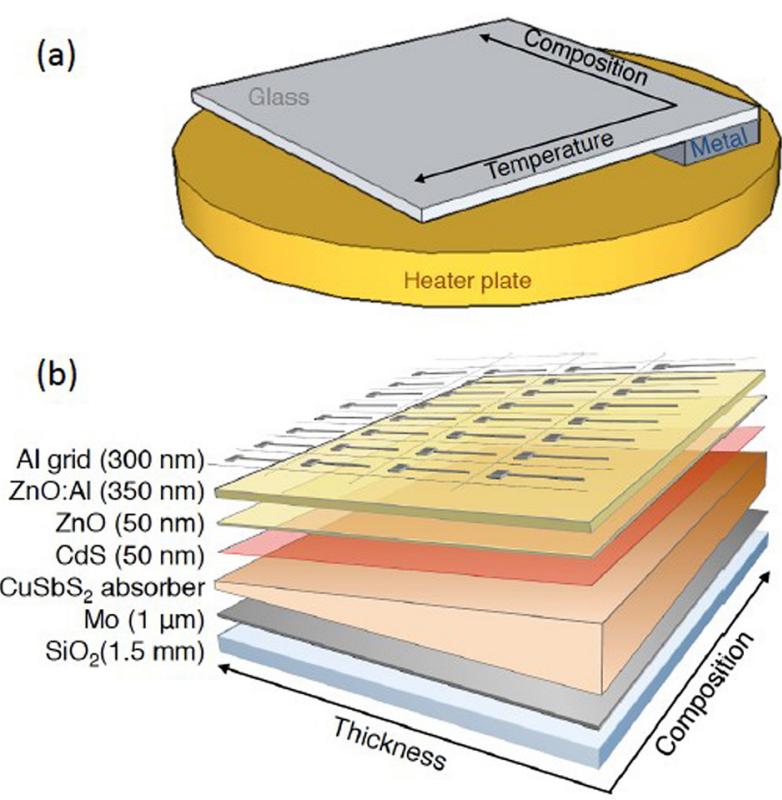

FIG. 1. (a) Schematic of a combinatorial heater for achieving continuous temperature gradients orthogonal to composition gradients. A small piece of metal is inserted between the heater plate and the glass substrate and (b) combinatorial photovoltaic device library with mutually orthogonal gradients in thickness and composition of the absorber. Each solar cell on the library has an individual front contact and a common back contact.

industrial sector consumes approximately one third of all energy, roughly $32 \times 10^{15}$ (quadrillion) Btu per year. Of this amount, between 5 and 13 quadrillion Btu per year are lost as waste heat via streams of hot exhaust liquids and gases, as well as through heat conduction, convection, and radiation from manufacturing equipment and processes. ${ }^{46}$ Indeed, "...the United States is the Saudi Arabia of waste heat." "47 Recent studies have shown that for the United States alone, annual potential for electrical energy recovery from waste heat could be in the multi-terawatt range. ${ }^{48}$ Although thermoelectric devices have significant potential to recover waste heat from industrial processes, commercially available devices are only about $5 \%$ efficient. Therefore, discovery of higher efficiency thermoelectric materials using HTE is critical to enabling the practical recovery of waste heat. Materials that exhibit a large Seebeck coefficient, high electrical conductivity, and low thermal conductivity are considered candidates for use in thermoelectric applications; ${ }^{49,50}$ optimizing these transport properties improves the energy conversion efficiency. The efficiency and performance of thermoelectric power generation are proportional to the dimensionless figure of merit, $Z T$, of the material. $Z T=S^{2} \sigma T / k$, where $T$ is the absolute temperature, $S$ is the Seebeck coefficient, $\sigma$ is the electrical conductivity, and $k$ is the thermal conductivity. High-throughput instruments capable of locally and rapidly measuring Seebeck coefficients at room $^{51,52}$ and elevated temperatures ${ }^{53}$ have been constructed. Further, high-throughput measurements of thermal effusivity, from which thermal conductivity can be derived, have also been carried out, using either time domain ${ }^{54}$ or frequency domain thermoreflectance. ${ }^{55}$ Thus, $Z T$ can be obtained through HTE techniques; however, the power factor, equal to $S^{2} \sigma$, is also a suitable figure of merit and can be obtained more readily because it does not require measuring thermal conductivity. Figure 2, illustrating research performed on the $\mathrm{Ca}_{3} \mathrm{Co}_{4} \mathrm{O}_{9}$ system, ${ }^{56}$ shows the compositions on the library film that exhibit the highest power factors. HTE approaches have been applied in the search for new thermoelectric materials by diffusion annealing of bulk materials, ${ }^{57}$ unidirectional solidification ${ }^{58}$ and the use of compositionally graded thin films. ${ }^{51,53,55,59}$ Thus far, only a limited number of pseudo-binary and -ternary thermoelectric systems have been investigated using HTE: $(\mathrm{Zn}, \mathrm{Al}) \mathrm{O},{ }^{51} \mathrm{Ca}_{3} \mathrm{Co}_{4} \mathrm{O}_{9},{ }^{56}$ $\mathrm{Co}-\mathrm{Ce}-\mathrm{Sn},{ }^{55} \quad \mathrm{PbTe}-\mathrm{Ag}_{2} \mathrm{Te}-\mathrm{Sb}_{2} \mathrm{Te}_{3},{ }^{58} \quad \mathrm{Mg}_{\mathrm{x}} \mathrm{Si}_{\mathrm{y}} \mathrm{Ge}_{1-\mathrm{y}},{ }^{59}$ $\mathrm{CoSb}_{3}-\mathrm{LaFe}_{4} \mathrm{Sb}_{12}-\mathrm{CeFe}_{4} \mathrm{Sb}_{12}$ and $\mathrm{Sb}_{2} \mathrm{Te}_{3}-\mathrm{Bi}_{2} \mathrm{Te}_{3} .{ }^{53}$

\section{Energy storage: Battery materials}

Energy storage materials such as in $\mathrm{Li}$ ion batteries represent another opportunity for the HTE approach. The exponential growth of computer processing power, combined with the laws of physics expressed through quantum mechanics, has made it possible to design new materials from first principle physics using supercomputers. In the mid-2000s, the development of high-throughput computational methods and software infrastructure was pioneered and applied to the discovery of novel energy storage materials. $^{60,61}$ Importantly, HTE synthesis and measurement

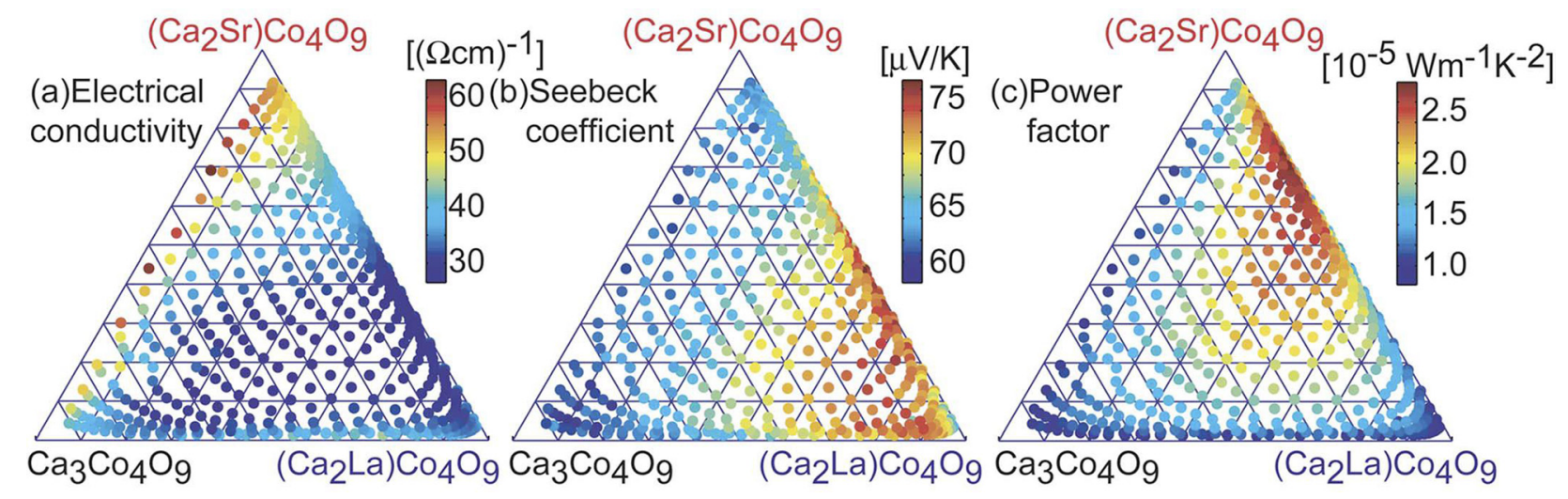

FIG. 2. (a) Electrical conductivity, (b) Seebeck coefficient, and (c) power factor of the composition-spread $\left(\mathrm{Ca}_{1-x-y} \mathrm{Sr}_{\mathrm{x}} \mathrm{La}_{\mathrm{y}}\right)_{3} \mathrm{Co}_{4} \mathrm{O}_{9}$ film $(0<\mathrm{x}<1 / 3$ and $0<\mathrm{y}<1 / 3$ ). Reproduced with permission from Appl. Phys. Lett. 91, 3 (2007). Copyright 2007 AIP Publishing LLC. ${ }^{56}$ 
techniques were also developed, which enable rapid validation and benchmarking of simulation and modeling data. ${ }^{62,63}$ Thousands of candidate Li-ion intercalation materials were screened for suitable properties such as phase stability, ionic diffusivity, capacity, and volume expansion. Several novel compounds were identified and subsequently synthesized and tested, including a monoclinic form of $\mathrm{LiMnBO}_{3},{ }^{64}$ layered $\mathrm{Li}_{9} \mathrm{~V}_{3}\left(\mathrm{P}_{2} \mathrm{O}_{7}\right)_{3}\left(\mathrm{PO}_{4}\right)_{2},{ }^{65} \mathrm{Cr}$-doped $\mathrm{LiVO}_{2},{ }^{66}$ and a new class of $\mathrm{Li}_{3} \mathrm{MPO}_{4} \mathrm{CO}_{3} \quad(\mathrm{M}=$ transition metal $)$ materials, which are unconventional in that they mix two different polyanion groups (phosphate and carbonate). ${ }^{67}$

Building upon the "Materials Project" infrastructure, ${ }^{68}$ the Joint Center for Energy Storage (JCESR) launched a highthroughput computational search for multivalent ion intercalation compounds as well as novel electrolyte formulations. Multivalent intercalation cathodes can exhibit very high energy density compared to their Li-ion counterparts, creating the materials innovation challenge of identifying host structures with sufficient ionic mobility. Systematically searching through redox-active cations and mobile multivalent species, Liu et al. ${ }^{69,70}$ predicted reasonable overall performance for $\mathrm{Mg}$ and $\mathrm{Ca}$ in the $\mathrm{Mn}$ oxide spinel structure (Fig. 3), as well as in the $\mathrm{Cr}$, Ti, and Mn sulfide spinels. Furthermore, Rong et $a l .^{71}$ formulated multivalent ionic mobility design rules as a function of structure type and coordination environment. Indeed, sluggish yet reversible $\mathrm{Mg}$ intercalation in $\mathrm{Mn}$ oxide spinels was subsequently proven ${ }^{72}$ and, excitingly, recent work $^{73}$ experimentally demonstrated well-behaved $\mathrm{Mg}$ intercalation in the cubic $\mathrm{TiS}_{2}$ spinel. The latter material yielded a voltage of $1.2 \mathrm{~V}$ and a capacity of $200 \mathrm{~mA} \mathrm{~h} / \mathrm{g}$ upon cycling at $60{ }^{\circ} \mathrm{C}$, almost double the energy density of the best performing multivalent cathode to date. ${ }^{74}$ Voltage and diffusivity measurements of both materials agreed with the predicted behavior. For liquid electrolyte energy storage applications, the JCESR-led "Electrolyte Genome",75,76 was developed to

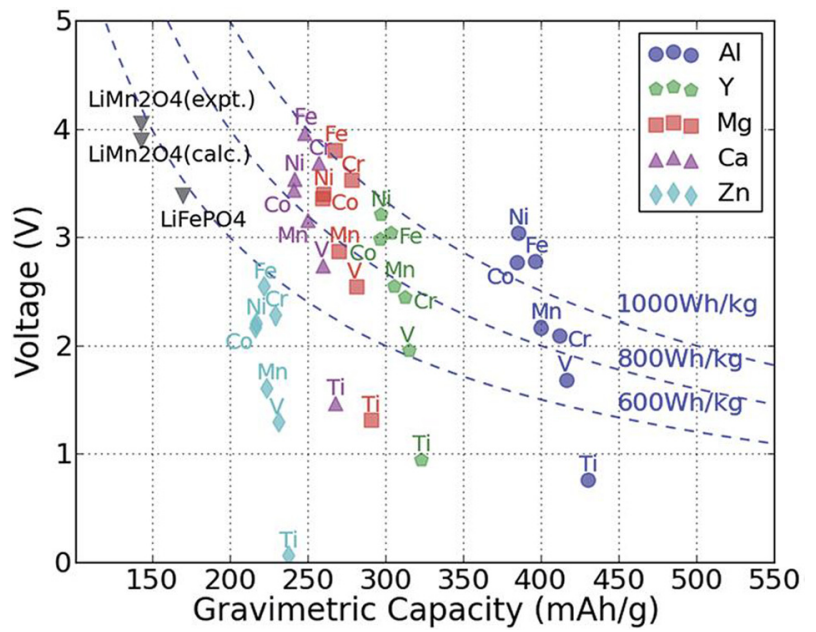

FIG. 3. The computed average voltage vs. gravimetric capacity for intercalation of $\mathrm{A}=\mathrm{Zn}, \mathrm{Ca}, \mathrm{Mg}, \mathrm{Y}$, and $\mathrm{Al}$ in various $\mathrm{M}_{2} \mathrm{O}_{4}$ spinels up to composition $\mathrm{AM}_{2} \mathrm{O}_{4}$. The redox-active metal is marked next to each point. Dashed curves show the specific energy of $600 \mathrm{Wh} \mathrm{kg}^{-1}, 800 \mathrm{~W} \mathrm{~h} \mathrm{~kg}^{-1}$, and 1000 $\mathrm{Wh} \mathrm{kg}{ }^{-1}$, respectively. The spinel $\mathrm{LiMn}_{2} \mathrm{O}_{4}$ and olivine $\mathrm{LiFePO}_{4}$ data points are also marked on the plot for comparison. Reproduced with permission from Energy Environ. Sci. 8(3), 964-974 (2015). Copyright 2015 The Royal Society of Chemistry. ${ }^{69}$ design novel molecular formulations for beyond-Li ion technologies. For example, an in-depth study of $\mathrm{Mg}$ electrolyte decomposition elucidated that strong ion pairing in $\mathrm{Mg}$ electrolytes, coupled with the multiple-electron charge transfer reaction at the negative electrode, leads to concentrationdependent interfacial decomposition reactions. Recent experimental work on ionic liquid $\mathrm{Mg}$ electrolytes ${ }^{77}$ similarly found that rational design of solvation structures is crucial to realizing novel systems with improved stability. Similar high-throughput computational efforts to search for more stable solvents for Li-air battery applications have also been undertaken. $^{78}$

Furthermore, there is a growing interest in solid state energy storage, and novel compounds exhibiting superfast Li-ion conduction have been predicted via high-throughput computations, ${ }^{79}$ and subsequently synthesized. ${ }^{80,81}$ HTE has thus far focused on solid state electrolytes, with a strategy of small compositional changes within one structure or compound family. For example, Beal et al. ${ }^{82}$ screened solid solution compositions in $\mathrm{Li}_{3 \mathrm{x}} \mathrm{La}_{2 / 3-\mathrm{x}} \mathrm{TiO}_{3}$ for fast $\mathrm{Li}$ conductivity and Yada et $a l .^{83}$ identified promising highly conducting dielectric interlayers for solid state $\mathrm{Li}$ batteries in the $\mathrm{Li}-\mathrm{Nb}$ Ta ternary oxide system.

\section{Microelectronic materials}

Over the last two decades, the number of elements (and therefore new materials) used in silicon microelectronics manufacturing has jumped from twelve to over fifty, as shown in Fig. 4. As device dimensions approach a few atomic layers, electronic wave functions and materials properties are dominated by surfaces and interfaces and can no longer be estimated from bulk behavior. The ability to understand and build lower power switches such as tunneling field-effect transistors, as well as interconnects with lower resistance, is fundamentally linked to an accurate understanding of atomic scale interfaces. A wealth of detailed experimental data will drive the design of complex three dimensional structures on the atomic scale. HTE has enabled advances in the microelectronics industry through development of advanced gate stack materials (high- $\kappa$ gate dielectrics and metal gate electrodes) and ferroelectric, piezoelectric, multiferroic, and magnetic oxide materials. ${ }^{4}$ Many developments in the semiconductor industry require continuous advancement in materials, multilevel thin film stacks, and their associated properties. From dimensional scaling, traditional lithography has transitioned to multipatterning, leveraging the confluence of deposition and etch during exposure. For example, low temperature atomic layer deposition (ALD) spacers with differing etch rates are utilized for pitch division strategies. These require screening of unique ALD ligands and ALD process parameters along with comparative etch rates and materials compatibility. Selective deposition further opens up ways to reduce patterning and integration costs. ${ }^{84}$

Traditional solution-based high-throughput techniques have been adapted to screen for new resist formulations, ${ }^{85}$ but some of the materials challenges associated with extreme ultraviolet lithography include advanced resists beyond 
a
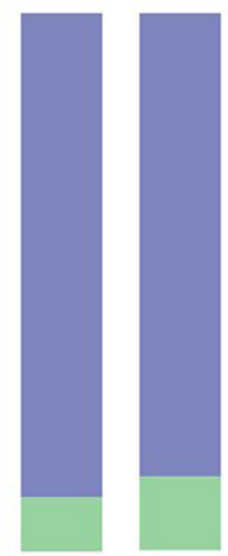

$180 \mathrm{~nm} 130 \mathrm{~nm}$ 1999

2001
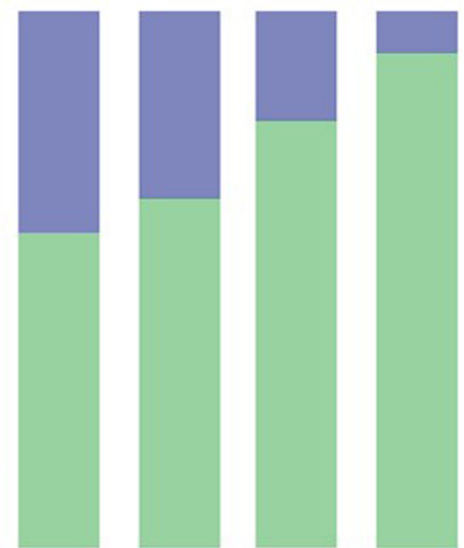

$90 \mathrm{~nm} 65 \mathrm{~nm}$ 2003

2005

$45 \mathrm{~nm}$ 20072009

$32 \mathrm{~nm} 22 \mathrm{~nm}$

traditional scaling

materials and device architecture innovation

b

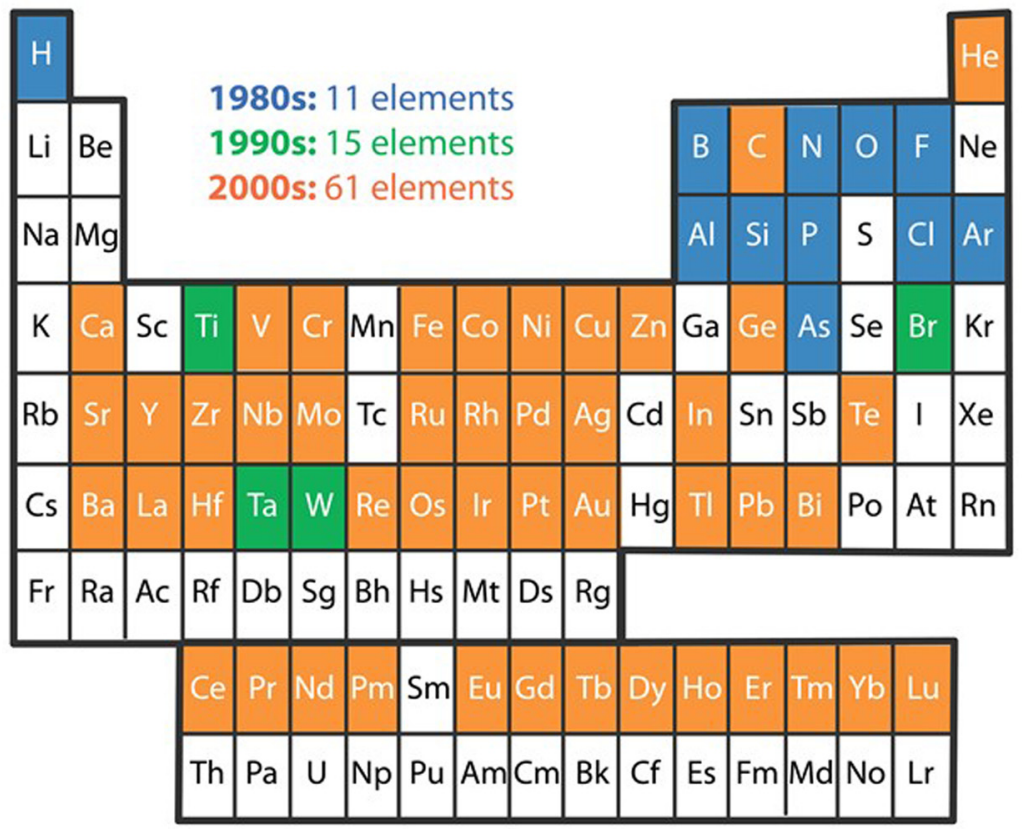

FIG. 4. Advances in materials innovation are critical to continued growth of the semiconductor industry: (a) the fraction of research and development spending by the semiconductor industry associated with traditional "scaling" vs. advanced materials development for a 12 year span of Moore's Law scaling, highlighting the critical nature of accelerating materials development for commercialization and (b) Periodic Table of the Elements, showing the elements used for semiconductor manufacturing from the 1980s to today. The rapid increase in the breadth of advanced materials must be considered when developing new semiconductor devices.

traditional chemically amplified resists. HTE must be applied to develop metal oxide resists that provide improved sensitivity, minimal line edge and line width roughness, and etch resistance.

Another emerging device area is $2 \mathrm{D}$ materials ${ }^{86}$ such as transition metal dichalcogenides, ${ }^{87}$ ferroelectric materials for negative-gate-capacitance field effect transistors, ${ }^{88}$ traditional field effect transistors, ferroelectric-dynamic random access memory cells, ${ }^{89}$ resistive random access memory cells, ${ }^{86}$ Mott field effect transistors, ${ }^{86}$ and chalcogenidebased memories, ${ }^{86}$ where specific materials properties are leveraged in conjunction with device behavior to enable transistor scaling of novel memory devices. Applying HTE methodologies in the aforementioned areas requires the means to process the materials in dimensionally and compositionally controlled thin film stacks, using relevant processing tools such as sputtering or ALD, and appropriate thermal budgets. Further, early device prototypes and test vehicles must be employed to more accurately and adequately assess their initial properties. Additionally, more advanced materials characterization techniques must be employed to understand the materials properties in conjunction with electrical characterization and analysis. For example, to tailor the ferroelectric behavior of $\mathrm{HfO}_{2}$-based materials for a particular device application, one must be able to quantitatively understand the statistically relevant control parameters such as precursor ligand, oxidant, underlying substrate, doping/alloying species and concentration, electrode materials, thermal history, and annealing conditions. Such an approach is in keeping with the aforementioned need for HTE libraries to include 
processing variables, as opposed to simply composition, as library parameters.

\section{Sustainable alloys for vehicular applications}

The development of Low Density High Entropy Alloys (LDHEAs) could provide an important advancement in automotive fuel efficiency, and the utility of an HTE platform for exploration of these advanced materials has recently been demonstrated..$^{90}$ Once candidate materials are identified, gradient film libraries can be rapidly synthesized and characterized at every composition point across the film. These libraries can then be screened for basic structural (e.g., phase, composition (as shown in Fig. 5), grain size) and mechanical properties (e.g., hardness using nano-indentation), as well as subjected to incremental anneals to gain insight into phase stability as a function of temperature and their correlation with mechanical properties.

LDHEAs have the potential to provide dramatically improved specific yield strength with a concomitant improvement in the balance between strength and ductility of metals, corrosion resistance, and reduced sensitivity to processing conditions. However, the complex and nuanced materials and process-phase space for LDHEAs make screening and optimizing bulk alloys much more time consuming than for traditional alloys. The HTE approach has the potential to screen broad compositional regions of complex alloys quickly, thereby significantly accelerating their development and optimization.

\section{Catalysts}

The field of catalysis spans a broad range of applications, as optimized catalysts are often needed to realize efficient, selective chemical reactions in applications ranging from medicine to renewable fuels. In the context of HTE and the establishment of structure-property relationships, catalysis research may be conceptually separated into small-molecule and solid-state-materials categories. The deep roots and continued prevalence of HTE in pharmaceutical research enable efficient exploration for small molecule functionalization in medicinal chemistry ${ }^{91}$ and reaction discovery in synthetic chemistry. ${ }^{92}$ Due to the role that molecular structure plays in facilitating a chemical reaction, structure-activity relationships are prevalent in small molecule catalysis and motivate integration of HTE methods with descriptor-based catalyst design from statistical or theoretical computation. ${ }^{93}$ Indeed, a hallmark achievement in the catalysis field resulted from a Dow Chemical Corporation computation-guided HTE program that yielded the now industrialized process for synthesizing
InFuse $^{\mathrm{TM}}$ olefin block copolymers (OBCS). This two-year project produced new theoretically predicted materials (at times more than 1600 individual polymerization reactions were evaluated during a three-week period), optimized production, and rapidly commercialized a new class of polymers now made at scales exceeding $10^{8}$ pounds per year. ${ }^{94}$

Implementations of HTE in basic catalyst research are typically focused on their discovery and informatics. Currently, there are rapidly increasing efforts in solid-state heterogeneous catalysis due to its importance to a variety of emerging technologies, especially renewable energy technologies where earth-abundant catalysts are highly desirable. $^{12,95}$ The quality of HTE catalyst screening has significantly improved due to the recent development of HTE electrochemical cells ${ }^{96-98}$ and detection of reaction products for both gas-phase catalysis ${ }^{99,100}$ and electrocatalysis, ${ }^{101}$ which is critical for identification of catalysts with high selectivity. The discovery of heterogeneous catalysts requires particular implementations of HTE strategies for establishing structure-property relationships (of course, this same complexity argument applies to other classes of materials, e.g., photovoltaic materials); while materials properties such as band gap energy and superconducting critical temperature correspond to a particular composition and crystal structure, mixed-phase materials can enable new reaction pathways in catalysis due to effects such as spillover and catalyst-support interactions. ${ }^{102}$ As a result, the materials search space includes vast combinations of elements in highdimensional composition spaces. An emerging application of HTE is the mapping of composition-activity relationships to discover composition spaces that exhibit unique catalytic properties, followed by the evaluation of computational predictions using such results. ${ }^{103}$ The state-of-the-art with respect to experimental throughput has been reported by Haber et al. ${ }^{104,105}$ where thousands of mixed metal oxides (Fig. 6) were screened as electrocatalysts for the oxygen evolution reaction, a critical component of electrolysis and solar fuels technologies. An HTE-discovered quinary oxide catalyst was found to contain nanoparticles of two different phases with atomically sharp interfaces, demonstrating the importance of phase mixtures in optimizing performance. ${ }^{106}$

Because catalytic activity can strongly depend on morphology and the support material, novel implementations of HTE are often required to discover deployable catalysts, as demonstrated in the optimization of electrocatalyst particle size and supports, ${ }^{107,108}$ and discovery of nanoparticle alloy electrocatalysts, with direct integration into an operational fuel cell. ${ }^{109}$ The need to bridge the traditional gap between
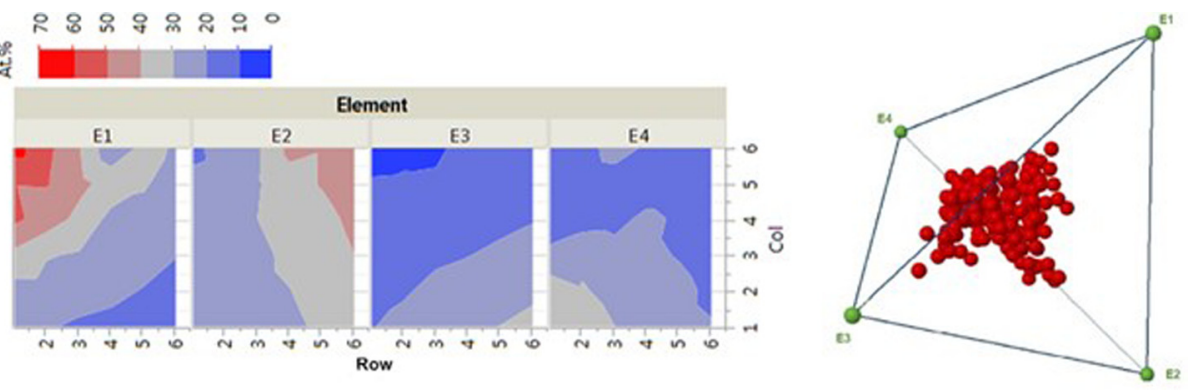

FIG. 5. Example of data richness (composition, measured using energy dispersive spectroscopy) for a quaternary AlCrTiZn alloy $\left(\mathrm{E}_{1,2,3,4}=\right.$ elements $)$ generated from one gradient deposition on one library sample. 


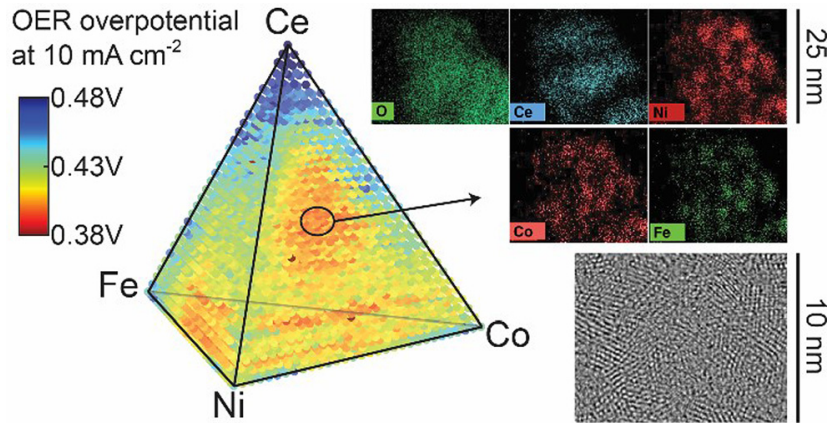

FIG. 6. High-throughput screening of 5456 metal oxide electrocatalysts for the oxygen evolution reaction, demonstrating the discovery of Ce-rich catalysts comprised of an intimate mixture of ceria and transition metal oxide catalysts (from Haber et al. ${ }^{105}$ ).

discovery and deployment underscores the immediate impact of HTE, ${ }^{104}$ and as recently demonstrated by combinatorial integration of catalysts into solar fuels photoanodes, fabrication of device components can yield surprising discoveries and enhancements in performance. ${ }^{110,111}$ The suite of HTE techniques in the catalysis field comprise perhaps the most advanced technology for rapid characterization of surfaces and interfaces, which directly addresses the key recommendations from the HTE workshop. ${ }^{16}$ An added benefit of the use of HTE is the potential to explore atypical catalyst-support formulations, which can result in significant increases in both catalytic performance and mitigation of deactivation mechanisms, an often overlooked aspect of catalyst design. ${ }^{112,113}$

\section{Sensors}

Sensor materials and devices have a long history in HTE because the complex interactions that dictate their performance and reliability are best optimized using high throughput techniques. $^{7}$ Factors affecting the performance of sensor materials may include physical integrity of the multilayer devices, film microstructure, and contamination levels. Further, the operation and reliability of sensors may be sensitive to humidity and temperature. HTE can be used to rapidly characterize variations in sensor response, as well as validate optimal sensor designs. Sensors are essentially transducers, used to convert a signal of one type (chemical, electrical, optical, etc.) into a signal of another type. In mechanical sensors changes in mass on a cantilever device, ${ }^{114}$ for example, may be sensed as a deflection, by optical means such as a laser. ${ }^{115}$ Further, electrical sensors may undergo changes in resistance or capacitance as a result of, for example, a sensor-chemical interaction. ${ }^{116}$

The majority of sensors explored by HTE have been made of polymers, due to the relative ease and low cost of fabrication. Of these, the most common polymers utilized were formulated with fluorescent materials for fast optical responses or conductive polymers for fast electrical responses. Semiconducting metal oxide sensors that exhibit changes in electrical resistance as a result of chemical reduction, for example, have also been developed. Growth in the nascent "Internet of Things"117 will accelerate development of entire new classes of sensors, which in turn will require advanced electronic technologies including flexible, postCMOS (e.g., graphene) devices.

\section{CHALLENGES FOR HTE}

The HTE approach consists of three major steps, shown in Fig. 7: (a) hypothesis-driven design and synthesis of a "library" sample with variations in the materials parameter(s) of interest ${ }^{118-121}$ (typically composition); (b) rapid, local, and automated interrogation of the library for the properties of interest; ${ }^{53,122-128}$ and (c) analysis, mining, display, and curation of the resultant data. ${ }^{129-131}$ Each step presents current challenges that must be overcome before HTE methodologies can be widely deployed.

\section{High-throughput synthesis and characterization of materials libraries}

Library synthesis and metrology tools are often expensive and not readily available commercially and therefore

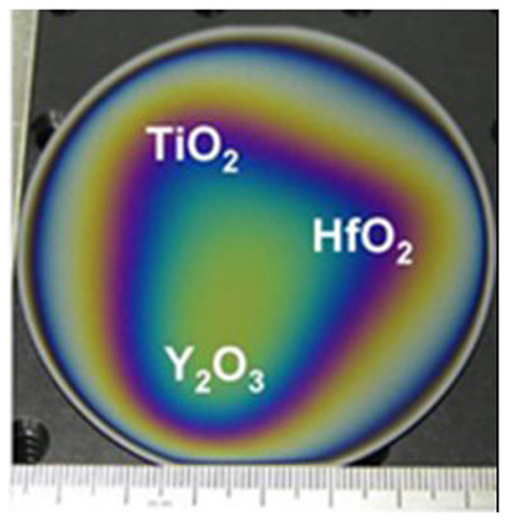

(a)

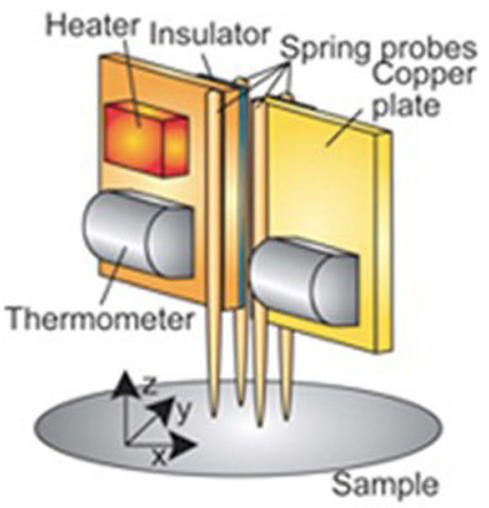

(b)

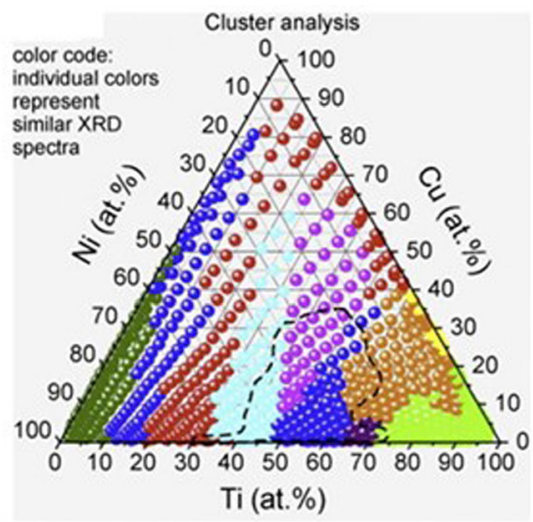

(c)

FIG. 7. Typical examples of the three components of a high-throughput experiment. (a) Library synthesis (for a high dielectric constant oxide system). Reproduced with permission from Schenck et al., Thin Solid Films 517(2), 691-694 (2008). Copyright 2008 Elsevier S.A.; ${ }^{132}$ (b) local and rapid measurement of the property of interest (for a thermoelectric oxide system), Reproduced with permission from Appl. Phys. Lett. 91, 3 (2007). Copyright 2007 AIP Publishing LLC; ${ }^{56}$ and (c) rapid cluster analysis of diffraction spectra taken from a Ni-Ti-Cu library, Reproduced with permission from Zarnetta et al., Intermetallics 26, 98-109 (2012). Copyright 2012 Elsevier Ltd. ${ }^{133}$ 
not accessible to most materials researchers. Currently, HTE libraries and measurement tools are primarily designed with the goal of materials discovery and optimization; therefore, composition is the most common variable HTE parameter. Further, library samples are not usually deposited using the processing tools and conditions eventually required to produce the intended material or device. Library design must evolve so that the libraries increasingly represent the actual materials and processing conditions that the selected materials will be exposed to during device production. Solar cells, fuel cells, and transistors, for example, all require the integration of multiple materials with different functionalities. These devices all contain numerous interfaces, such as the $\mathrm{p}-\mathrm{n}$ junction in photovoltaics, or the solid-water catalytic interface in photoelectric water splitting. The properties of these interfaces are the defining functional properties of the devices enabled by the constituent materials. Therefore, HTE techniques should be additionally applied to processing parameters, interface engineering, and performance of multilayer stacks/devices. Foundational demonstrations of HTE screening for integrated materials have been made in the fields of photovoltaics ${ }^{37,134}$ and solar fuels. ${ }^{135}$ To further the evolution of HTE technologies for component-level materials development, it is necessary to develop HTE metrologies that measure interface properties (e.g., electronic, magnetoelectric, and photonic) and grain boundary effects on device performance and reliability.

Library synthesis and metrology tools require dedicated staff to operate, calibrate, and maintain them. HTE characterization tools for composition and materials structure, e.g., $\mathrm{X}$-ray fluorescence and X-ray diffractometers, are available at synchrotron beam lines and some laboratories, but HTE methods to characterize surfaces, interfaces, or chemical bonding are not widely deployed. Finally, while HTE synthesis tools have been optimized for the production of thin films, many new bulk materials are in demand, including lightweight structural materials for transportation and rare earth-free magnetic materials for electrical power generation in direct-drive wind turbines. There is, therefore, a need for the development of HTE bulk materials synthesis techniques.

\section{Data curation and analysis and databases}

For HTE to effectively address MGI goals, the ever increasing amount of data generated must be curated, analyzed, and mined to transform it into knowledge. The HTE workshop report ${ }^{16}$ recognized HTE methodologies to be uniquely suited to rapidly generate the large volumes of high-quality data required to populate materials databases. Currently, a lack of high quality materials data, and the difficulty of accessing that data, presents a barrier to the MGI scheme. ${ }^{129}$ Many experimental and computational materials property databases exist (see Table III for a partial list), but often the data are not in an interoperable format nor they are certified, vetted, or validated. Most importantly, the metadata is often incomplete or absent, making it difficult to search and compare available data.
The HTE workshop report ${ }^{16}$ also noted that opportunities and capabilities in data capture, curation, and analysis are underdeveloped. The problems broadly affecting the community are as follows: (i) instrument output data formats are diverse, poorly described, and often not machine readable except by vendor-specific software and (ii) material measurement data are complex, with conditions and variables unique to a specific body of research. While many data repositories have flourished for specific techniques, such as high-throughput calculations, ${ }^{65,139,168}$ general file repositories tailored to materials science, ${ }^{169}$ with rich metadata, ${ }^{170}$ would benefit the broader materials community. ${ }^{171-174}$ Additionally, while for-profit materials information management and analysis providers are available to the materials community, ${ }^{144,175-177}$ a deliberate effort must be mounted to develop community data and metadata standards to enable widespread, interoperable data exchange. ${ }^{178}$

NIST's ${ }^{179}$ Information Technology ${ }^{180}$ and Material Measurement Laboratories, ${ }^{181}$ for one, are developing software underpinning the "Materials Innovation Infrastructure," including the "Materials Resource Registry (MRR)",182 and the "Materials Data Curation System (MDCS)."183,184 The MRR allows global searches for resources (e.g., a HTE data repository), where each resource may have different access protocols. The MDCS is designed to enable community data and metadata standards and allows a search for individual results across distributed networks of HTE repositories, based on MDCS software.

\section{Distributed experimental tools and data platforms}

Many instances of HTE facilities and data platforms exist (see examples in Table II), but they are distributed over government, academic and industrial enterprises, with few mechanisms for interaction. Currently, there are no national physical facilities dedicated to a comprehensive and sustained (one- to five-year) HTE approach for novel materials discovery and commercialization. A major goal, therefore, should be an effort to deploy a federated network of highthroughput synthesis and characterization tools and repositories and registries for experimental data, which enable integration with the existing infrastructure for computational materials science. A "HTE Materials Virtual Laboratory (HTE-MVL)""185 would accelerate the development of new materials via HTE methodologies, integrated computational tools, and a data infrastructure that complements and accelerates the research process. The library synthesis and sample characterization equipment, as well as the data registries, would be geographically distributed in such a model.

The HTE-MVL could be the platform for a national or international infrastructure that functions as illustrated in Fig. 8, in which the virtual laboratory is created by adopting and integrating a number of localized HTE synthesis and characterization tools as well as materials data infrastructure tools. Most of the data tools are open-source and currently exist or are under active development. The virtual laboratory would be deployed in stages starting now, and could, for example, be an enabling concept for the US DOE's recent Energy Materials Network programs, ${ }^{186}$ e.g., LightMAT, 
TABLE III. Partial list of computational and/or experimental materials property databases.

\begin{tabular}{|c|c|c|c|}
\hline Name & Owner & Content & Fee? $(\mathrm{Y} / \mathrm{N})$ \\
\hline $\begin{array}{l}\text { Aerospace Structural } \\
\text { Metals Database (ASMD) })^{136}\end{array}$ & CINDAS LLC & Properties of $255+$ high strength, lightweight alloys & $\mathrm{N}$ \\
\hline $\begin{array}{l}\text { Automated Interactive Infrastructure } \\
\text { and Database for Computational } \\
\text { Science (AiiDA) }{ }^{137}\end{array}$ & $\begin{array}{l}\text { École Polytechnique Fédérale } \\
\text { de Lausanne (Switzerland) } \\
\text { The Bosch Research } \\
\text { and Technology Center (USA) }\end{array}$ & $\begin{array}{l}\text { Informatics infrastructure to manage, } \\
\text { preserve, and disseminate the simulations, } \\
\text { data, and workflows of computational science. }\end{array}$ & $\mathrm{N}$ \\
\hline ASM Online Databases ${ }^{138}$ & ASM International & $\begin{array}{l}\text { Metals and alloys databases } \\
\text { (e.g., phase diagrams, mechanical } \\
\text { properties, corrosion, and } \\
\text { micrographs) }\end{array}$ & $\mathrm{Y}$ \\
\hline $\begin{array}{l}\text { Automatic Flow for Materials } \\
\text { Discovery (AFLOW) }{ }^{139}\end{array}$ & Duke University & $\begin{array}{l}\text { Property data for } \sim 1500000 \\
\text { materials, as well as } \sim 150000000 \\
\text { calculated properties }\end{array}$ & $\mathrm{N}$ \\
\hline Citrination $^{140}$ & Citrine & $\begin{array}{l}\text { Structure-property-process } \\
\text { relationships for over } \\
17 \text { million materials }\end{array}$ & $\mathrm{N}$ \\
\hline $\begin{array}{l}\text { CRC Handbook of Materials } \\
\text { Properties }\end{array}$ & CRC Press & $\begin{array}{l}\text { Comprehensive physical and structural } \\
\text { properties data for engineering materials }\end{array}$ & $\mathrm{Y}$ \\
\hline $\begin{array}{l}\text { Crystallography Open Database } \\
(\mathrm{COD})^{142}\end{array}$ & Materials Design & $\begin{array}{l}\text { Open-access collection of } \sim 300000 \text { crystal } \\
\text { structures of organic, inorganic, } \\
\text { metal-organic compounds and minerals }\end{array}$ & $\mathrm{N}$ \\
\hline Electrolytic Genome ${ }^{143}$ & $\begin{array}{l}\text { Joint Center for Energy } \\
\text { Storage Research (DOE) }\end{array}$ & $\begin{array}{l}\text { Project to accelerate the discovery of } \\
\text { battery electrolytes by computer } \\
\text { simulation and experimental validation }\end{array}$ & $\mathrm{N}$ \\
\hline Granta Data Series ${ }^{144}$ & Granta & $\begin{array}{l}\text { Extensive catalog of property data for } \\
\text { a wide range of materials classes }\end{array}$ & $\mathrm{Y}$ \\
\hline Hydrogen Storage Materials Database ${ }^{145}$ & Department of Energy & $\begin{array}{l}\text { Properties data for adsorbents, } \\
\text { chemical hydrides, metal hydrides }\end{array}$ & $\mathrm{N}$ \\
\hline Infotherm $^{146}$ & John Wiley and Sons & $\begin{array}{l}\text { Thermodynamic and physical } \\
\text { properties of organic, inorganic, } \\
\text { and organometallic compounds }\end{array}$ & Y \\
\hline $\begin{array}{l}\text { Inorganic Crystal Structure } \\
\text { Database (ICSD) }\end{array}$ & $\begin{array}{l}\text { Fachinformationszentrum } \\
\text { Karlsruhe-Leibniz Institute } \\
\text { for Information Infrastructure (FIZ) }\end{array}$ & $\begin{array}{l}\sim 177000 \text { peer-reviewed } \\
\text { inorganic crystal structure data } \\
\text { entries including atomic coordinates }\end{array}$ & $\mathrm{Y}$ \\
\hline MARVEL $^{148}$ & Swiss National Science Foundation & $\begin{array}{l}\text { Accelerated design and discovery of } \\
\text { novel materials via a materials informatics } \\
\text { platform of database-driven, } \\
\text { high-throughput quantum simulations }\end{array}$ & $\mathrm{N}$ \\
\hline Materials Database (MatDB) $)^{149}$ & National Renewable Energy Laboratory & $\begin{array}{l}\text { Computational materials database focusing } \\
\text { on materials for renewable energy } \\
\text { applications such as photovoltaic materials, } \\
\text { catalysts, thermoelectrics; Also, DFT relaxed } \\
\text { crystal structures, thermochemical properties, } \\
\text { and quasiparticle energy calculations } \\
\text { providing accurate band-gaps } \\
\text { and dielectric functions }\end{array}$ & $\mathrm{N}$ \\
\hline $\begin{array}{l}\text { Materials and Processes Technical } \\
\text { Information System (MAPTIS) })^{150}\end{array}$ & NASA & $\begin{array}{l}\text { Physical, mechanical, and environmental } \\
\text { properties for metallic and } \\
\text { non-metallic materials used in } \\
\text { space and aerospace applications }\end{array}$ & $\mathrm{N}$ \\
\hline Material Property Data (MatWeb) ${ }^{151}$ & MatWeb & $\begin{array}{l}\text { Data sheets of polymers, metals, } \\
\text { ceramics, semiconductors, fibers, } \\
\text { and other engineering materials }\end{array}$ & $\mathrm{N}$ \\
\hline $\begin{array}{l}\text { Material Properties Database and } \\
\text { Estimation Tool (MatDat) }\end{array}$ & Matdat.com & $\begin{array}{l}\text { Metals properties databases with } \sim 800 \\
\text { datasets on steels, aluminum alloys, } \\
\text { titanium alloys, weld materials, } \\
\text { and other alloys }\end{array}$ & $\begin{array}{c}\mathrm{N} \text { (additional } \\
\text { data for purchase) }\end{array}$ \\
\hline The Materials Project ${ }^{153}$ & Lawrence Berkeley National Laboratory & $\begin{array}{l}\text { Access to computed information on known } \\
\text { and predicted materials, as well as } \\
\text { analysis tools to design novel materials }\end{array}$ & $\mathrm{N}$ \\
\hline MedeA $^{154}$ & Materials Design Inc. & $\begin{array}{l}\text { Software package for atomistic scale } \\
\text { simulation of materials properties, } \\
\text { using ICSD, Pearson and } \\
\text { Pauling databases }\end{array}$ & $\mathrm{Y}$ \\
\hline
\end{tabular}


TABLE III. (Continued.)

\begin{tabular}{|c|c|c|c|}
\hline Name & Owner & Content & Fee? $(\mathrm{Y} / \mathrm{N})$ \\
\hline $\begin{array}{l}\text { Microelectronics Packaging } \\
\text { Materials Database (MPMD) }\end{array}$ & CINDAS LLC & $\begin{array}{l}\text { Properties of } 1025+\text { electronics } \\
\text { packaging materials }\end{array}$ & $\mathrm{Y}$ \\
\hline NIMS Materials Database (MatNavi) ${ }^{156}$ & $\begin{array}{l}\text { National Institute of } \\
\text { Materials Science (Japan) }\end{array}$ & $\begin{array}{l}\text { Scientific and engineering materials } \\
\text { database including crystal structures, } \\
\text { diffusion data, creep and fatigue data }\end{array}$ & $\mathrm{N}$ \\
\hline NIST Alloy Data ${ }^{157}$ & $\begin{array}{l}\text { National Institute of } \\
\text { Standards and Technology }\end{array}$ & $\begin{array}{l}\text { Thermophysical property data } \\
\text { with a focus on unary, binary, } \\
\text { and ternary metal systems }\end{array}$ & $\mathrm{N}$ \\
\hline NIST Data Gateway ${ }^{158}$ & $\begin{array}{l}\text { National Institute of } \\
\text { Standards and Technology }\end{array}$ & $\begin{array}{l}\text { Properties data for a broad range } \\
\text { of materials and substances } \\
\text { from many different } \\
\text { scientific disciplines }\end{array}$ & $\begin{array}{l}\mathrm{N} \text { (additional data } \\
\text { for purchase) }\end{array}$ \\
\hline $\begin{array}{l}\text { Novel Materials Discovery } \\
\text { Laboratory (NOMAD) }{ }^{159}\end{array}$ & European Union Center of Excellence & $\begin{array}{l}\text { Materials Encyclopedia, Big-Data Analytics } \\
\text { and Advanced Graphics Tools } \\
\text { for materials science and engineering }\end{array}$ & $\begin{array}{l}\mathrm{N} \text { (additional data } \\
\text { for purchase) }\end{array}$ \\
\hline $\begin{array}{l}\text { Open Quantum Materials } \\
\text { Database (OQMD) }\end{array}$ & Northwestern University & $\begin{array}{l}\text { DFT calculated thermodynamic } \\
\text { and structural properties } \\
\text { for } \sim 475000 \text { materials }\end{array}$ & $\mathrm{N}$ \\
\hline Pauling File ${ }^{161}$ & Material Phases Data System (MPDS) & $\begin{array}{l}\text { Phase diagrams, crystal structures, } \\
\text { and physical properties } \\
\text { databases for inorganic compounds }\end{array}$ & $\mathrm{Y}$ \\
\hline Pearson's Crystal Data (PCD) ${ }^{162}$ & $\begin{array}{l}\text { ASM International } \\
\text { Materials Phases Data System }\end{array}$ & $\begin{array}{l}\text { Crystal structure database for } \\
\text { inorganic compounds, } \\
\text { including } \sim 165000 \text { chemical formulas }\end{array}$ & $\mathrm{Y}$ \\
\hline Prospector $^{163}$ & UL & $\begin{array}{l}\text { Materials and ingredients search } \\
\text { engine offering technical information } \\
\text { for commercial products }\end{array}$ & $\begin{array}{l}\mathrm{N} \text { (additional data } \\
\text { for purchase) }\end{array}$ \\
\hline SpringerMaterials ${ }^{164}$ & Springer Nature & $\begin{array}{l}\text { Physical and chemical properties } \\
\text { of } \sim 250000 \text { materials and chemical systems }\end{array}$ & $\mathrm{Y}$ \\
\hline $\begin{array}{l}\text { Substances and Materials } \\
\text { Databases (Knovel) }\end{array}$ & Elsevier & $\begin{array}{l}\text { Mechanical, chemical, corrosion, etc., } \\
\text { properties data for a wide range } \\
\text { of materials and coatings }\end{array}$ & $\mathrm{Y}$ \\
\hline Thermodynamics Research Center ${ }^{166}$ & $\begin{array}{l}\text { National Institute of Standards } \\
\text { and Technology }\end{array}$ & $\begin{array}{l}\text { Thermodynamic properties tables, thermophysical } \\
\text { properties data, models, and standards } \\
\text { for a wide variety of compounds, } \\
\text { binary mixtures, ternary mixtures, } \\
\text { and chemical reactions }\end{array}$ & $\begin{array}{l}\mathrm{N} \text { (additional data } \\
\text { for purchase) }\end{array}$ \\
\hline $\begin{array}{l}\text { Thermophysical Properties } \\
\text { of Matter Database (TPMD) }{ }^{167}\end{array}$ & CINDAS LLC & $\begin{array}{l}\text { Thermophysical properties } \\
\text { of } 5000+\text { materials }\end{array}$ & $\mathrm{Y}$ \\
\hline
\end{tabular}

CaloriCool, and ElectroCat. Data infrastructure products could be integrated with HTE research equipment throughout the lifecycle of the traveling combinatorial sample library. Member institutions, responsible for the synthesis and characterization of sample libraries, would have to deploy systems for (i) laboratory information management, (ii) domain-specific and/or user-defined structured data and metadata management, and (iii) endpoints to a data transfer grid. Features (i) and (ii) can be addressed by two similar open-source efforts, the Integrated Collaborative Environment $^{187}$ (ICE) and the Timely and Trustworthy Curating and Coordinating Data Framework ${ }^{188}$ (T2C2), which are developing robust and comprehensive platforms to automate data capture and accelerate materials research within a large facility. If a member institution already has a system for feature (i) but lacks a system for feature (ii), the Materials Data Curation System ${ }^{183,184}$ (MDCS) could complement an existing infrastructure. Finally, Globus ${ }^{171}$ is well suited for transfer of data among institutions, including the user's home institution.
A dedicated HTE Resource Registry, which would be discoverable from the NIST Materials Resource Registry ${ }^{182}$ (MRR), would allow for global tracking of all data/metadata associated with a given library sample. A registry record for a sample library would enumerate unique resolvable identifiers (e.g., handles ${ }^{189}$ ) for all data/metadata records associated with the sample library. Note that a handle is merely a pointer to a dataset, which could be private and behind a firewall. Furthermore, a single handle would be assigned to the sample library registry record, which would enable one-step discovery of all data and metadata associated with a sample library. HTE instruments would also be registered, which would enable optimal design of experiment across the federated network of instruments and institutions. Furthermore, the handles associated with samples and instruments could be transformed into Quick Response ${ }^{190}(\mathrm{QR})$ codes, as shown in Fig. 9. This would enable the development of new tablet applications that enable automated association of the sample library to new measurement data, thus integrating an electronic lab notebook device with the laboratory data 


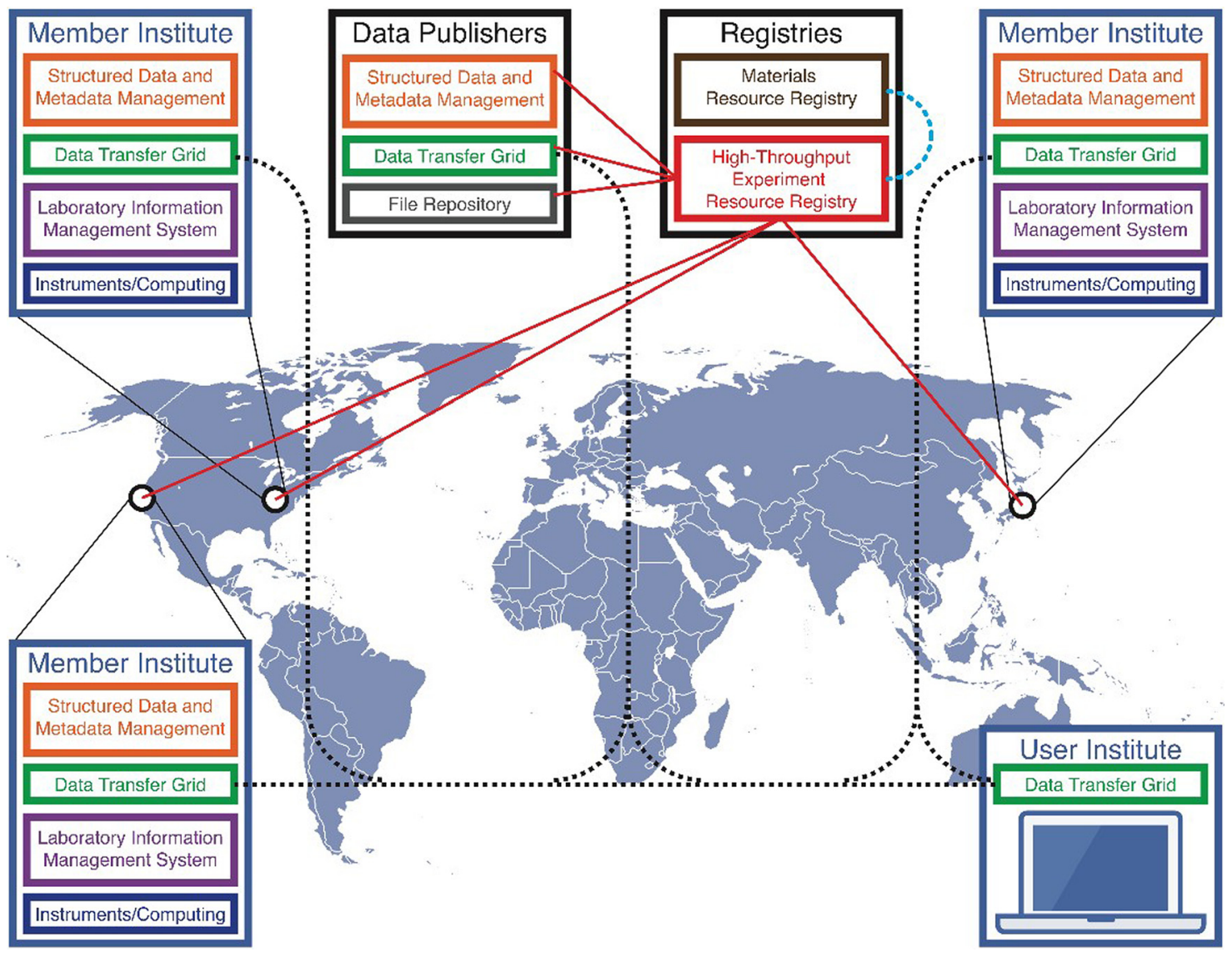

FIG. 8. Schematic illustration of a HTE Materials Virtual (HTE-MVL) Laboratory.

infrastructure. ${ }^{191}$ A number of opportunities exist for making HTE data (at least for the case of publically funded data) discoverable, accessible, and interoperable. At a high level, HTE repositories and registries would be discoverable via the NIST MRR. ${ }^{182}$ Individual HTE datasets would be searchable at the individual HTE repositories and registries, with faceted search optimized for the HTE community. In terms of accessibility, a number of centralized resources allow for

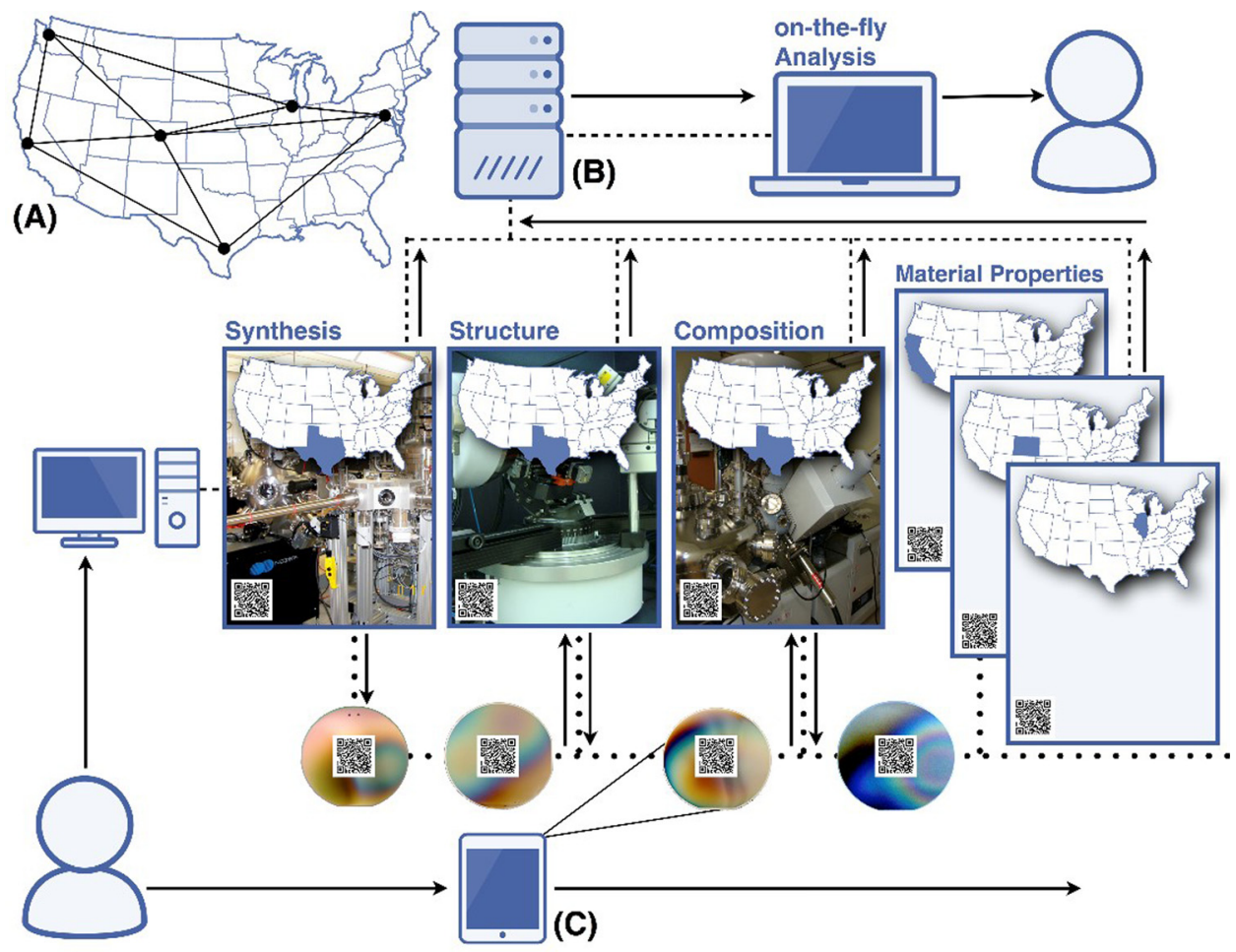

FIG. 9. Illustration of automationassisted management of HTE samples, data, and physical infrastructure: (a) the "HTE Materials Virtual Laboratory," also shown in Fig. 8, (b) an automated laboratory information management system, and (c) tablet application for automated sample/data management. 


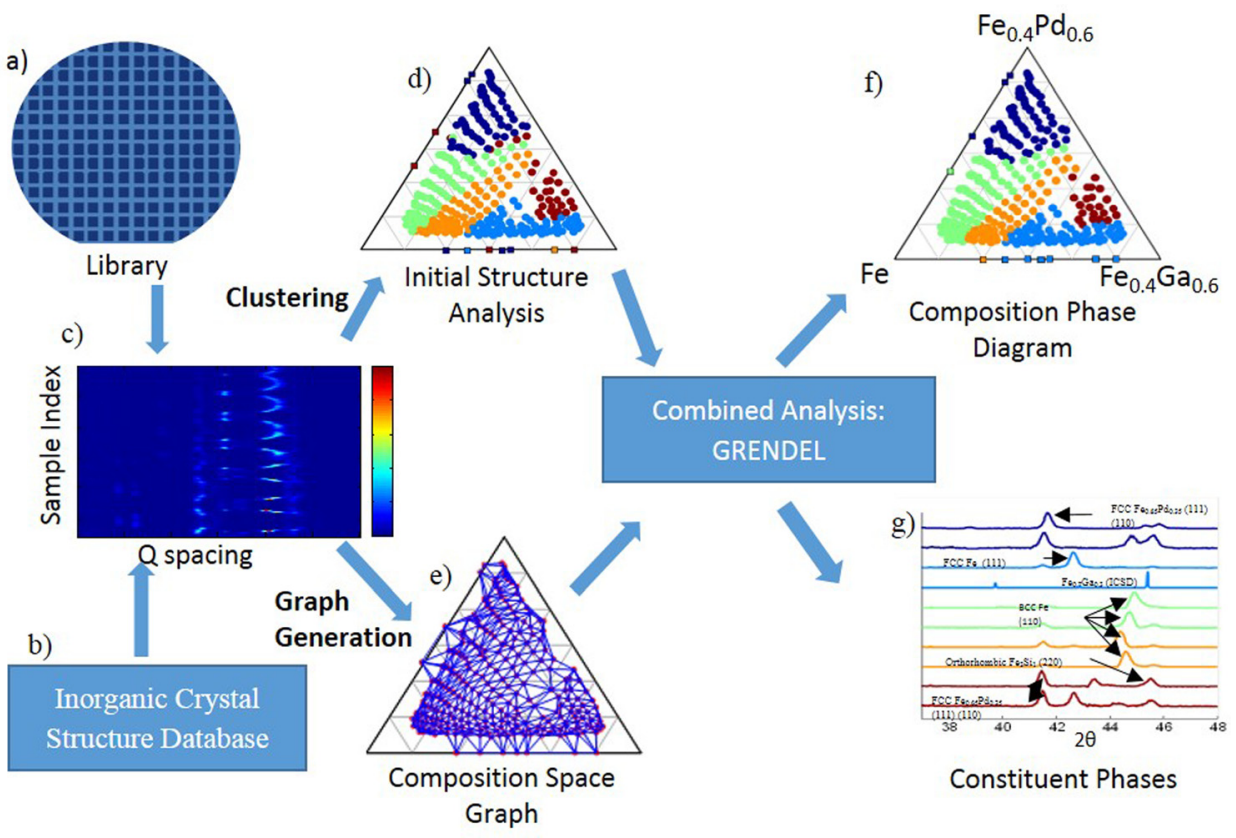

FIG. 10. Example of informatics methodologies applied to the Fe-Ga-Pd system. Reproduced with permission from Kusne et al. Nanotechnology 26(44), 444002 (2015). Copyright 2015 Creative Commons (license available at https://creativecommons.org/licenses/ by/3.0/legalcode). ${ }^{130}$

data dissemination, ${ }^{172,176}$ including one that is based on the Globus infrastructure. ${ }^{192,193}$ However, individual HTE research groups may wish to deploy and maintain their own repositories, and the MDCS ${ }^{184}$ software could enable them to do so. Finally, to enable interoperability, NIST is developing modular community data standards and coordinating adoption among various projects, including MDCS, ${ }^{184}$ $\mathrm{ICE},{ }^{187}$ and T2C $2{ }^{188}$

\section{Informatics}

When materials registries, repositories, and curation systems are in place and networked, the materials community will encounter an exponential growth in the volume of accessible data. For example, the National Synchrotron Light Source II at Brookhaven National Laboratory is expected to generate between 15 and 20 petabytes of materials data per year. ${ }^{194}$ Appropriate application of machine learning ${ }^{195}$ techniques will be critical to capitalize on the scientific value of such large data volumes. Analysis can be performed by the vast array of machine learning algorithms that have successfully extracted actionable knowledge in a range of fields including social networks, ${ }^{196}$ genetics, ${ }^{197}$ and finance. ${ }^{198}$ Similarly, it can be used to mine materials data, for example, composition-structure relationships, from large amounts of computational and experimental materials data, as is illustrated in Fig. 10. The benefits of machine learning for accelerated materials data analysis have already been realized, with numerous studies showing the great potential for research and discovery. ${ }^{199-201}$ These studies include a wide range of materials analysis challenges including crystal structure $^{202-204}$ and phase diagram ${ }^{130,205-207}$ determination, materials property predictions, ${ }^{208,209}$ micrograph analy$\mathrm{sis}^{210,211}$ development of interatomic potentials ${ }^{212-214}$ and energy functionals ${ }^{215}$ to improve materials simulations, and on-the-fly data analysis of high-throughput experiments. ${ }^{216}$

\section{Educational component}

Scientific initiatives have been efficient drivers to train and educate future workforces. The multidisciplinary Nanotechnology Initiative ${ }^{217}$ is a good example and model for MGI. The classroom is a necessary element of the MGI, where a comprehensive Lab-to-Market-to-Classroom (LMC) paradigm $^{218}$ allows for the delivery of practical, hands-on MGI-type content. The LMC concept builds upon the effectiveness of interactive, project-based learning, ${ }^{219}$ which are strongly student-driven and ideal for instilling MGI principles in students. HTE methodologies present a substantial educational opportunity, i.e., the potential to invest in synthesis, measurement, and data science for materials discovery and commercialization, for the next generation of materials scientists. Universities are crucial for a diverse and flexible MGI-ready workforce. Opportunities in this area include open access educational resources such as webbased video tutorials on experimental best practices, experimental and data-driven materials courses, and MGI lectures, all based on emerging materials problems. Further, creating opportunities for students and faculty to contribute in industry and government labs will strengthen the "lab-to-market" pipeline by exposing them to development and production challenges, providing academic expertise in industrial settings, and promoting commercialization of university research. This can be facilitated by providing access to the HTE-MVL in an analogous way as for other national user facilities (e.g., synchrotron beamlines and neutron sources). Data Science (data acquisition, curation, database construction, data mining, and machine learning algorithms) has been identified as a critically missing element in current materials science curricula.

\section{PATH FORWARD}

The authors propose the following strategic action items to enable HTE, a key component of the MGI, to significantly 
contribute to accelerated materials discovery and commercialization (these action items are the opinions of the authors, not necessarily the organization they represent):

(1) Identify critical technologies that are currently materialsconstrained, such as cost-effective batteries, ultra-high temperature metals for turbines in next-generation natural gas power plants, low cost and high efficiency solar cells, low power multiplexed sensors for flexible electronics, $\mathrm{CO}_{2}$ hydrogenation and selective methane oxidation catalysts, chemical and biological sensors, and earth abundant substitute materials for critical elements.

(2) Establish key specific targets for desired materials properties and performance and fund a "HTE Materials Virtual Laboratory" with dedicated teams and infrastructure for tackling specific materials topics that hold promise for immediate impacts (e.g., within three years).

(3) Enable user access to the HTE-MVL through an on-line submission process. A flexible array of manufacturing grade HTE tools should be available to academic groups and the larger community, especially small companies and startups with the need for rapid progress; access to such a system could foster a "lab-to-fab" culture for this segment of the community.

(4) Ensure that data science and management are integral to the HTE-MVL and connected to the best computational tools for large data analysis, including machine learning. All data sets and databases should be interoperable, incorporate an application programming interface (API), and use common formats, analysis protocols and informatics platforms.

(5) Establish HTE standards. Standardized R and D platforms (both physical and virtual) for testing libraries and metrology tools will be required. Standard library formats should be developed.

(6) Develop new chemical and physical HTE metrologies within the HTE-MVL. Further, HTE versions of standard characterization tools, such as x-ray fluorescence, micron-scale X-ray beams, atom probes, XPS, and in situ synthesis monitoring, for example, are needed.

\section{ACKNOWLEDGMENTS}

We are grateful to Alex King, John Newsam, John Perkins, Abhijit V. Shevade, John Smythe, and Ji-Cheng Zhao for manuscript input, and Andrey Dobrynin, Tom Kalil, Om Nalamasu, Nag Patibandla, Shannon Sullivan, and the National Science Foundation (DMR Grant No. 1439054) for their critical role in making the workshop ${ }^{16}$ possible. J.M.G. acknowledges support from the Joint Center for Artificial Photosynthesis, a DOE Energy Innovation Hub, supported through the Office of Science of the U.S. Department of Energy Award No. DE-SC0004993. A.Z. was supported by U.S. DOE, as a part of a Laboratory Directed Research and Development (LDRD) program, under Contract No. DE-AC36-08GO28308 to NREL.

Certain commercial equipment, instruments, or materials are identified in this paper to adequately specify the experimental procedure. Such identification does not imply recommendation or endorsement by the National Institute of Standards and Technology, nor does it imply that the materials or equipment identified are necessarily the best available for the purpose.

${ }^{1}$ See https://www.whitehouse.gov/sites/default/files/microsites/ostp/NSTC/ mgi_strategic_plan_-_dec_2014.pdf for Materials Genome Initiative Strategic Plan, 2014.

${ }^{2}$ Z. H. Barber and M. G. Blamire, Mater. Sci. Technol. 24(7), 757-770 (2008).

${ }^{3}$ J. N. Cawse, Experimental Design for Combinatorial and High Throughput Materials Development (John Wiley and Sons, New York, 2003).

${ }^{4}$ M. L. Green, I. Takeuchi, and J. R. Hattrick-Simpers, J. Appl. Phys. 113(23), 231101 (2013).

${ }^{5}$ H. Koinuma and I. Takeuchi, Nat. Mater. 3, 429-438 (2004).

${ }^{6}$ W. F. Maier, K. Stoewe, and S. Sieg, Angew. Chem. - Int. Ed. 46(32), 6016-6067 (2007).

${ }^{7}$ R. A. Potyrailo and V. M. Mirsky, Chem. Rev. 108(2), 770-813 (2008).

${ }^{8}$ I. Takeuchi, R. B. van Dover, and H. Koinuma, MRS Bull. 27(4), 301-308 (2002).

${ }^{9}$ X. D. Xiang, X. D. Sun, G. Briceno, Y. L. Lou, K. A. Wang, H. Y. Chang, W. G. Wallace-Freedman, S. W. Chen, and P. G. Schultz, Science 268(5218), 1738-1740 (1995).

${ }^{10} \mathrm{X}$. D. Xiang and I. Takeuchi, Combinatorial Materials Synthesis (Marcel Dekker, Inc., New York, 2003).

${ }^{11}$ B. J. Chisholm and D. C. Webster, J. Coat. Technol. Res. 4(1), 1-12 (2007).

${ }^{12}$ J. M. Newsam, Oil Gas Sci. Technol. 70(3), 437-446 (2015).

${ }^{13}$ R. A. Potyrailo and V. M. Mirsky, Combinatorial Methods for Chemical and Biological Sensors (Springer, Berlin, 2011).

${ }^{14}$ X. D. Xiang and P. G. Schultz, Physica C 282, 428-430 (1997).

${ }^{15}$ J. C. Zhao, Prog. Mater. Sci. 51(5), 557-631 (2006).

${ }^{16}$ See http://www.appliedmaterials.com/company/news/events/workshopon-combinatorial-approaches-to-functional-materials for Workshop on Combinatorial Approaches to Functional Materials, 2015.

${ }^{17} \mathrm{See}$ http://efrc.cst.temple.edu/ for Center for the Computational Design of Functional Layered Materials (CCDM), 2017.

${ }^{18}$ See http://www.ccmd.psu.edu/ for Center for Computational Materials Design (CCMD), 2013.

${ }^{19}$ See https://ceimm.jhu.edu/ for Center of Excellence on Integrated Materials Modeling (CEIMM), 2017.

${ }^{20}$ See http://chimad.northwestern.edu/ for Center for Hierarchical Materials Design (CHiMaD), 2016.

${ }^{21}$ See http://hemi.jhu.edu/cmede/ for Center for Materials in Extreme Dynamic Environments (CMEDE), 2017.

${ }^{22}$ See http://www.cngmd-efrc.org/ for Center for Next Generation of Materials by Design: Incorporating Metastability (CNGMD), 2017.

${ }^{23}$ See http://www.nist.gov/mml/ctcms/ for Center for Theoretical and Computational Materials Science (CTCMS), 2016.

${ }^{24}$ See http://www.exmatex.org/ for Exascale Co-design Center for Materials in Extreme Environments (ExMatEx), 2012.

${ }^{25}$ See http://www1.chem.umn.edu/icdc/ for Inorganometallic Catalyst Design Center (ICDC), 2017.

${ }^{26}$ See http://solarfuelshub.org/ for Joint Center for Artificial Photosynthesis (JCAP), 2017.

${ }^{27} \mathrm{See}$ http://www1.chem.umn.edu/nmgc/ for Nanoporous Materials Genome Center (NMGC), 2017.

${ }^{28}$ See http://www.prisms-center.org/\#/home for Predictive Integrated Structural Materials Science (PRISMS), 2016.

${ }^{29}$ See http://faculty.ims.uconn.edu/ MURI/ for Rational Design of Advanced Polymeric Capacitor Films, 2016.

${ }^{30}$ N. G. Park, Mater. Today 18(2), 65-72 (2015).

${ }^{31}$ K. M. Abraham, J. Phys. Chem. Lett. 6(5), 830-844 (2015).

${ }^{32}$ D. A. Medvedev, J. G. Lyagaeva, E. V. Gorbova, A. K. Demin, and P. Tsiakaras, Prog. Mater. Sci. 75, 38-79 (2016).

${ }^{33}$ C. M. Caskey, R. M. Richards, D. S. Ginley, and A. Zakutayev, Mater. Horiz. 1(4), 424-430 (2014).

${ }^{34}$ H. Stein, D. Naujoks, D. Grochla, C. Khare, R. Gutkowski, S. Grutzke, W. Schuhmann, and A. Ludwig, Phys. Status Solidi A 212(12), 2798-2804 (2015).

${ }^{35}$ A. Subramaniyan, J. D. Perkins, R. P. O’Hayre, S. Lany, V. Stevanovic, D. S. Ginley, and A. Zakutayev, APL Mater. 2(2), 022105 (2014). 
${ }^{36}$ A. Zakutayev, N. H. Perry, T. O. Mason, D. S. Ginley, and S. Lany, Appl. Phys. Lett. 103(23), 232106 (2013).

${ }^{37}$ S. Siol, T. P. Dhakal, G. S. Gudavalli, P. P. Rajbhandari, C. DeHart, L. L. Baranowski, and A. Zakutayev, ACS Appl. Mater. Interfaces 8, 14004 (2016).

${ }^{38}$ I. Ohkubo, H. M. Christen, S. V. Kalinin, G. E. Jellison, C. M. Rouleau, and D. H. Lowndes, Appl. Phys. Lett. 84(8), 1350-1352 (2004).

${ }^{39}$ T. Koida, D. Komiyama, H. Koinuma, M. Ohtani, M. Lippmaa, and M. Kawasaki, Appl. Phys. Lett. 80(4), 565-567 (2002).

${ }^{40}$ J. Eid, H. F. Liang, I. Gereige, S. Lee, and J. Van Duren, Prog. Photovoltaics 23(3), 269-280 (2015)

${ }^{41}$ H. F. Liang, W. Liu, S. Lee, J. van Duren, T. Franklin, M. Patten, and S. Nijhawan, in 2012 38th IEEE Photovoltaic Specialists Conference (PVSC) (2012), pp. 3102-3107.

${ }^{42}$ A. D. Collord, H. Xin, and H. W. Hillhouse, IEEE J. Photovoltaics 5(1), 288-298 (2015).

${ }^{43}$ A. W. Welch, L. L. Baranowski, P. Zawadzki, S. Lany, C. A. Wolden, and A. Zakutayev, Appl. Phys. Express 8(8), 082301 (2015).

${ }^{44}$ B. Kupfer, K. Majhi, D. A. Keller, Y. Bouhadana, S. Ruhle, H. N. Barad, A. Y. Anderson, and A. Zaban, Adv. Energy Mater. 5(1), 1401007 (2015).

${ }^{45}$ M. Pavan, S. Ruhle, A. Ginsburg, D. A. Keller, H. N. Barad, P. M. Sberna, D. Nunes, R. Martins, A. Y. Anderson, A. Zaban, and E. Fortunato, Sol. Energy Mater. Sol. Cells 132, 549-556 (2015).

${ }^{46} \mathrm{~W}$. T. Choate and I. Johnson, see http://www1.eere.energy.gov/manufacturing/intensiveprocesses/pdfs/waste_heat_recovery.pdf for Waste Heat Recovery: Technology and Opportunities in U.S. Industry, 2008.

${ }^{47}$ E. Wesoff, see http://www.greentechmedia.com/articles/read/WasteHeat-is-Everywhere-But-Can-it-Be-Economically-Recovered for Waste Heat Is Everywhere-But Can It Be Economically Recovered?, 2015.

${ }^{48}$ A. I. Hochbaum, R. K. Chen, R. D. Delgado, W. J. Liang, E. C. Garnett, M. Najarian, A. Majumdar, and P. D. Yang, Nature 451(7175), 163-165 (2008).

${ }^{49}$ G. S. Nolas, J. Sharp, and J. Goldsmid, Thermoelectrics: Basic Principles and New Materials Developments (Springer, 2001).

${ }^{50}$ D. M. Rowe, Thermoelectrics Handbook: Macro to Nano (CRC Press, 2005).

${ }^{51}$ M. Otani, K. Itaka, W. Wong-Ng, P. K. Schenck, and H. Koinuma, Appl. Surf. Sci. 254(3), 765-767 (2007).

${ }^{52}$ R. D. Snyder, E. L. Thomas, and A. A. Voevodin, Thin Solid Films 596, 233-241 (2015).

${ }^{53}$ Y. G. Yan, J. Martin, W. Wong-Ng, M. Green, and X. F. Tang, Rev. Sci. Instrum. 84(11), 115110 (2013).

${ }^{54}$ D. G. Cahill, Rev. Sci. Instrum. 75(12), 5119-5122 (2004),

${ }^{55}$ M. Otani, E. L. Thomas, W. Wong-Ng, P. K. Schenck, K. S. Chang, N. D. Lowhorn, M. L. Green, and H. Ohguchi, Jpn. J. Appl. Phys., Part 1 48(5), 05EB02 (2009).

${ }^{56}$ M. Otani, N. D. Lowhorn, P. K. Schenck, W. Wong-Ng, M. L. Green, K. Itaka, and H. Koinuma, Appl. Phys. Lett. 91, 132102 (2007).

${ }^{57}$ A. Yamamoto, H. Obara, and K. Ueno, in MRS Fall Meeting, edited by T. P. Hogan, J. Yang, R. Funahashi, and T. Tritt (Materials Research Society, Boston, 2007), Vol. 1044, pp. 273-278.

${ }^{58}$ T. Ikeda, S. Iwanaga, H. J. Wu, N. J. Marolf, S. W. Chen, and G. J. Snyder, J. Mater. Chem. 22(46), 24335-24347 (2012).

${ }^{59}$ M. Watanabe, T. Kita, T. Fukumura, A. Ohtomo, K. Ueno, and M. Kawasaki, J. Comb. Chem. 10(2), 175-178 (2008).

${ }^{60}$ A. Jain, G. Hautier, C. J. Moore, S. P. Ong, C. C. Fischer, T. Mueller, K. A. Persson, and G. Ceder, Comput. Mater. Sci. 50(8), 2295-2310 (2011).

${ }^{61}$ G. Ceder and K. Persson, Sci. Am. 309(6), 36-40 (2013).

${ }^{62}$ M. D. Fleischauer, T. D. Hatchard, G. P. Rockwell, J. M. Topple, S. Trussler, S. K. Jericho, M. H. Jericho, and J. R. Dahn, J. Electrochem. Soc. 150(11), A1465-A1469 (2003).

${ }^{63}$ M. D. Fleischauer, J. M. Topple, and J. R. Dahn, Electrochem. Solid State Lett. 8(2), A137-A140 (2005).

${ }^{64}$ J. C. Kim, C. J. Moore, B. Kang, G. Hautier, A. Jain, and G. Ceder, J. Electrochem. Soc. 158(3), A309-A315 (2011).

${ }^{65}$ A. Jain, G. Hautier, C. Moore, B. Kang, J. Lee, H. L. Chen, N. Twu, and G. Ceder, J. Electrochem. Soc. 159(5), A622-A633 (2012).

${ }^{66}$ X. H. Ma, G. Hautier, A. Jain, R. Doe, and G. Ceder, J. Electrochem. Soc. 160(2), A279-A284 (2013).

${ }^{67}$ G. Hautier, A. Jain, H. L. Chen, C. Moore, S. P. Ong, and G. Ceder, J. Mater. Chem. 21(43), 17147-17153 (2011).

${ }^{68}$ A. Jain, S. P. Ong, G. Hautier, W. Chen, W. D. Richards, S. Dacek, S. Cholia, D. Gunter, D. Skinner, G. Ceder, and K. A. Persson, APL Mater. 1(1), 011002 (2013).

${ }^{69}$ M. Liu, Z. Rong, R. Malik, P. Canepa, A. Jain, G. Ceder, and K. A. Persson, Energy Environ. Sci. 8(3), 964-974 (2015).
${ }^{70}$ M. Liu, A. Jain, Z. Rong, X. Qu, P. Canepa, R. Malik, G. Ceder, and K. A. Persson, Energy Environ. Sci. 9, 3201 (2016).

${ }^{71}$ Z. Q. Rong, R. Malik, P. Canepa, G. S. Gautam, M. Liu, A. Jain, K. Persson, and G. Ceder, Chem. Mater. 27(17), 6016-6021 (2015).

${ }^{72}$ C. Kim, P. J. Phillips, B. Key, T. Yi, D. Nordlund, Y.-S. Yu, R. D. Bayliss, S.-D. Han, M. He, Z. Zhang, A. K. Burrell, R. F. Klie, and J. Cabana, Adv. Mater. 27, 3377-3384 (2015).

${ }^{73}$ X. Sun, P. Bonnick, V. Duffort, M. Liu, Z. Rong, K. A. Persson, G. Ceder, and L. F. Nazar, Energy Environ. Sci. 9, 2273 (2016).

${ }^{74}$ Z. L. D. Aurbach, A. Schechter, Y. Gofer, H. Gizbar, R. Turgeman, Y. Cohen, M. Moshkovich, and E. Levi, Nature 407, 724-727 (2000).

${ }^{75}$ X. H. Qu, A. Jain, N. N. Rajput, L. Cheng, Y. Zhang, S. P. Ong, M. Brafman, E. Maginn, L. A. Curtiss, and K. A. Persson, Comput. Mater. Sci. 103, 56-67 (2015).

${ }^{76}$ L. Cheng, R. S. Assary, X. H. Qu, A. Jain, S. P. Ong, N. N. Rajput, K. Persson, and L. A. Curtiss, J. Phys. Chem. Lett. 6(2), 283-291 (2015).

${ }^{77}$ A. K. T. Watkins and D. A. Buttry, J. Am. Chem. Soc. 138, 641-650 (2016).

${ }^{78}$ M. Korth, Phys. Chem. Chem. Phys. 16(17), 7919-7926 (2014).

${ }^{79}$ S. P. Ong, Y. F. Mo, W. D. Richards, L. Miara, H. S. Lee, and G. Ceder, Energy Environ. Sci. 6(1), 148-156 (2013).

${ }^{80}$ A. Kuhn, O. Gerbig, C. B. Zhu, F. Falkenberg, J. Maier, and B. V. Lotsch, Phys. Chem. Chem. Phys. 16(28), 14669-14674 (2014).

${ }^{81}$ P. Bron, S. Johansson, K. Zick, J. S. auf der Gunne, S. Dehnen, and B. Roling, J. Am. Chem. Soc. 135(42), 15694-15697 (2013).

${ }^{82}$ M. S. Beal, B. E. Hayden, T. Le Gall, C. E. Lee, X. J. Lu, M. Mirsaneh, C. Mormiche, D. Pasero, D. C. A. Smith, A. Weld, C. Yada, and S. Yokoishi, ACS Comb. Sci. 13(4), 375-381 (2011).

${ }^{83}$ C. Yada, C. E. Lee, D. Laughman, L. Hannah, H. Iba, and B. E. Hayden, J. Electrochem. Soc. 162(4), A722-A726 (2015).

${ }^{84}$ A. J. M. Mackus, A. A. Bol, and W. M. M. Kessels, Nanoscale 6(19), 10941-10960 (2014)

${ }^{85}$ F. Wieberger, T. Kolb, C. Neuber, C. K. Ober, and H.-W. Schmidt, Molecules 18(4), 4120-4139 (2013).

${ }^{86}$ A. Chen, J. Hutchby, V. Zhirnov, and G. Bourianoff, editors, Emerging Nanoelectronic Devices (Wiley, 2015).

${ }^{87}$ Q. H. Wang, K. Kalantar-Zadeh, A. Kis, J. N. Coleman, and M. S. Strano, Nat. Nanotechnol. 7(11), 699-712 (2012).

${ }^{88}$ A. I. Khan, K. Chatterjee, B. Wang, S. Drapcho, L. You, C. Serrao, S. R. Bakaul, R. Ramesh, and S. Salahuddin, Nat. Mater. 14(2), 182-186 (2015).

${ }^{89}$ T. P. Ma, in 6th International Memory Workshop (IEEE, 2014).

${ }^{90}$ D. B. Miracle, J. D. Miller, O. N. Senkov, C. Woodward, M. D. Uchic, and J. Tiley, Entropy 16(1), 494-525 (2014).

${ }^{91}$ T. Cernak, K. D. Dykstra, S. Tyagarajan, P. Vachal, and S. W. Krska, Chem. Soc. Rev. 45(3), 546-576 (2016).

${ }^{92}$ K. D. Collins, T. Gensch, and F. Glorius, Nat. Chem. 6(10), 859-871 (2014).

${ }^{93}$ E. Burello and G. Rothenberg, Int. J. Mol. Sci. 7(9), 375-404 (2006).

${ }^{94}$ P. S. Chum and K. W. Swogger, Prog. Polym. Sci. 33(8), 797-819 (2008).

${ }^{95}$ P. J. McGinn, Mater. Discov. 1, 38 (2015).

${ }^{96}$ J. M. Gregoire, C. Xiang, X. Liu, M. Marcin, and J. Jin, Rev. Sci. Instrum. 84(2), 024102 (2013).

${ }^{97}$ J. P. Kollender, A. I. Mardare, and A. W. Hassel, Electrochim. Acta 179, 32-37 (2015).

${ }^{98}$ H. Ye, J. Lee, J. S. Jang, and A. J. Bard, J. Phys. Chem. C 114(31), 13322-13328 (2010).

${ }^{99}$ P. J. Cong, R. D. Doolen, Q. Fan, D. M. Giaquinta, S. H. Guan, E. W. McFarland, D. M. Poojary, K. Self, H. W. Turner, and W. H. Weinberg, Angew. Chem. - Int. Ed. 38(4), 484-488 (1999).

${ }^{100}$ C. M. Snively, G. Oskarsdottir, and J. Lauterbach, Angew. Chem. - Int. Ed. 40(16), 3028-3030 (2001).

${ }^{101}$ J.-P. Grote, A. R. Zeradjanin, S. Cherevko, and K. J. J. Mayrhofer, Rev. Sci. Instrum. 85(10), 104101 (2014).

${ }^{102}$ E. W. McFarland and H. Metiu, Chem. Rev. 113(6), 4391-4427 (2013).

${ }^{103}$ J. Hattrick-Simpers, C. Wen, and J. Lauterbach, Catal. Lett. 145(1), 290-298 (2014).

${ }^{104}$ J. A. Haber, Y. Cai, S. Jung, C. Xiang, S. Mitrovic, J. Jin, A. T. Bell, and J. M. Gregoire, Energy Environ. Sci. 7(2), 682-688 (2014).

${ }^{105} \mathrm{~J}$. A. Haber, D. Guevarra, S. Jung, J. Jin, and J. M. Gregoire, ChemElectroChem 1(10), 1613-1617 (2014).

${ }^{106} \mathrm{~J}$. A. Haber, E. Anzenburg, J. Yano, C. Kisielowski, and J. M. Gregoire, Adv. Energy Mater. 5(10), 1402307 (2015).

${ }^{107}$ A. Anastasopoulos, J. C. Davies, L. Hannah, B. E. Hayden, C. E. Lee, C. Milhano, C. Mormiche, and L. Offin, ChemSusChem 6(10), 1973-1982 (2013). 
${ }^{108}$ B. E. Hayden, Acc. Chem. Res. 46(8), 1858-1866 (2013).

${ }^{109}$ T. S. Almeida, A. R. Van Wassen, R. B. VanDover, A. R. de Andrade, and H. D. Abruña, J. Power Sources 284, 623-630 (2015).

${ }^{110}$ D. Guevarra, A. Shinde, S. K. Suram, I. D. Sharp, F. M. Toma, J. A. Haber, and J. M. Gregoire, Energy Environ. Sci. 9(2), 565-580 (2016).

${ }^{111}$ A. Shinde, D. Guevarra, J. A. Haber, J. Jin, and J. M. Gregoire, J. Mater. Res. 30(3), 442-450 (2015).

${ }^{112}$ J. E. Bedenbaugh, S. Kim, E. Sasmaz, and J. Lauterbach, ACS Comb. Sci. 15(9), 491-497 (2013).

${ }^{113}$ J. Lauterbach, E. Sasmaz, J. Bedenbaugh, S. Kim, and J. HattrickSimpers, in Modern Applications of High Throughput $R \& D$ in Heterogeneous Catalysis, edited by A. Hagemeyer and A. F. Volpe (Bentham Science, 2013), pp. 89-117.

${ }^{114}$ N. V. Lavrik, M. J. Sepaniak, and P. G. Datskos, Rev. Sci. Instrum. 75(7), 2229-2253 (2004).

${ }^{115}$ B. G. Burke and D. A. LaVan, Appl. Phys. Lett. 102(2), 021916 (2013).

${ }^{116}$ C. Arnold, M. Harms, and J. Goschnick, IEEE Sens. J. 2(3), 179-188 (2002).

${ }^{117} \mathrm{See}$ https://en.wikipedia.org/wiki/Internet_of_Things for Internet of Things, 2016

${ }^{118}$ N. D. Bassim, P. K. Schenck, M. Otani, and H. Oguchi, Rev. Sci. Instrum. 78(7), 072203 (2007)

${ }^{119}$ S. I. Woo, K. W. Kim, H. Y. Cho, K. S. Oh, M. K. Jeon, N. H. Tarte, T. S. Kim, and A. Mahmood, QSAR Comb. Sci. 24(1), 138-154 (2005).

${ }^{120}$ Y. Yamamoto, R. Takahashi, Y. Matsumoto, T. Chikyow, and H. Koinuma, Appl. Surf. Sci. 223(1-3), 9-13 (2004).

${ }^{121}$ J. S. Wang, Y. Yoo, C. Gao, I. Takeuchi, X. D. Sun, H. Y. Chang, X. D. Xiang, and P. G. Schultz, Science 279(5357), 1712-1714 (1998).

${ }^{122}$ Y. Aono, J. Sakurai, T. Ishida, A. Shimokohbe, and S. Hata, Appl. Phys. Express 3(12), 125601 (2010).

${ }^{123}$ S. C. Barron, M. P. Patel, N. Nguyen, N. V. Nguyen, and M. L. Green, Rev. Sci. Instrum. 86(11), 113903 (2015).

${ }^{124}$ T. R. Gao, Y. Q. Wu, S. Fackler, I. Kierzewski, Y. Zhang, A. Mehta, M. J. Kramer, and I. Takeuchi, Appl. Phys. Lett. 102(2), 022419 (2013).

${ }^{125}$ J. E. Katz, T. R. Gingrich, E. A. Santori, and N. S. Lewis, Energy Environ. Sci. 2(1), 103-112 (2009).

${ }^{126}$ T. H. Muster, A. Trinchi, T. A. Markley, D. Lau, P. Martin, A. Bradbury, A. Bendavid, and S. Dligatch, Electrochim. Acta 56(27), 9679-9699 (2011).

${ }^{127}$ J.-C. Zhao, X. Zheng, and D. G. Cahill, JOM 63(3), 40-44 (2011).

${ }^{128}$ X. Zheng, D. G. Cahill, P. Krasnochtchekov, R. S. Averback, and J. C. Zhao, Acta Mater. 55, 5177-5185 (2007).

${ }^{129}$ J. Hill, G. Mulholland, K. Persson, R. Seshadri, C. Wolverton, and B. Meredig, MRS Bull. 41(05), 399-409 (2016).

${ }^{130}$ A. G. Kusne, D. Keller, A. Anderson, A. Zaban, and I. Takeuchi, Nanotechnology 26(44), 444002 (2015).

${ }^{131}$ M. Z. Pesenson, S. Suram, and J. M. Gregoire, ACS Comb. Sci. 17(2), 130-136 (2015)

${ }^{132}$ P. K. Schenck, J. L. Klamo, N. D. Bassim, P. G. Burke, Y. B. Gerbig, and M. L. Green, Thin Solid Films 517(2), 691-694 (2008).

${ }^{133}$ R. Zarnetta, P. J. S. Buenconsejo, A. Savan, S. Thienhaus, and A. Ludwig, Intermetallics 26, 98-109 (2012).

${ }^{134}$ A. Y. Anderson, Y. Bouhadana, H.-N. Barad, B. Kupfer, E. RoshHodesh, H. Aviv, Y. R. Tischler, S. Rühle, and A. Zaban, ACS Comb. Sci. 16(2), 53-65 (2014).

${ }^{135}$ D. Guevarra, A. Shinde, S. K. Suram, I. D. Sharp, F. M. Toma, J. A. Haber, and J. M. Gregoire, Energy Environ. Sci. 9, 565 (2016).

${ }^{136}$ See https://cindasdata.com/products/asmd for Aerospace Structural Metals Database (ASMD), 2017.

${ }^{137}$ See http://www.aiida.net/ for Automated Interactive Infrastructure and Database for Computational Science (AiiDA), 2012.

${ }^{138} \mathrm{See} \quad \mathrm{http}: / / \mathrm{www}$.asminternational.org/materials-resources/online-databases for ASM Online Databases, 2017.

${ }^{139}$ See http://aflowlib.org/ for Automatic Flow for Materials Discovery (AFLOW), 2016

${ }^{140}$ See https://citrination.com for Citrination, 2016.

${ }^{141} \mathrm{~J}$. F. Shackelford and W. Alexander, CRC Materials Science and Engineering Handbook (CRC Press, 2000).

${ }^{142}$ See http://www.crystallography.net/cod/new.html for Crystallography Open database, 2017.

${ }^{143} \mathrm{See}$ http://www.jcesr.org/tag/electrolyte-genome/ for Electrolytic Genome, 2012.

${ }^{144}$ See https://www.grantadesign.com/products/data/ for Granta Data Series, 2017.
${ }^{145}$ See http://hydrogenmaterialssearch.govtools.us/ for Hydrogen Storage Materials Database.

${ }^{146}$ See http://www.infotherm.com/ for Infotherm, 2013.

${ }^{147}$ See https://icsd.fiz-karlsruhe.de/search/ forInorganic Crystal Structure Database (ICSD), 1998.

${ }^{148}$ See http://nccr-marvel.ch/de for MARVEL, 2014.

${ }^{149}$ See http://materials.nrel.gov/ for Materials Database (MatDB).

${ }^{150}$ See http://maptis.nasa.gov for Materials and Processes Technical Information System (MAPTIS).

${ }^{151}$ See http://www.matweb.com/ for Material Property Data, 1996.

${ }^{152}$ See https://www.matdat.com/ for Material Properties Database and Estimation Tool, 2011.

${ }^{153}$ See https://www.materialsproject.org/ for The Materials Project, 2012.

${ }^{154}$ See http://www.materialsdesign.com/medea for MedeA, 2017.

${ }^{155} \mathrm{See}$ https://cindasdata.com/products/mpmd for Microelectronics Packaging Materials Database, 2017.

${ }^{156}$ See http://mits.nims.go.jp/index_en.html for NIMS Materials Database (MatNavi).

${ }^{157}$ See http://trc.nist.gov/metals_data/ for NIST Alloy Data, 2017.

${ }^{158}$ See https://srdata.nist.gov/gateway/ for NIST Data Gateway, 2008.

${ }^{159}$ See https://nomad-coe.eu/ for Novel Materials Discovery Laboratory (NOMAD), 2015

${ }^{160}$ See http://wolverton.northwestern.edu/news/oqmdwebsiteislive for Open Quantum Materials Database (OQMD), 2017.

${ }^{161}$ See http://paulingfile.com/index.php?p=home for Pauling File, 2016.

${ }^{162}$ See http://www.crystalimpact.com/pcd/Default.htm for Pearson's Crystal Data - Crystal Structure Database for Inorganic Compounds, 2016.

${ }^{163}$ See https://www.ulprospector.com/en/na/?utm for Prospector, 2016.

${ }^{164}$ See http://www.springer.com/gb/products/databases-and-software/springermaterials for SpringerMaterials, 2016.

${ }^{165}$ See https://www.elsevier.com/solutions/knovel-engineering-information/ substance-material-databases for Substances and Material Databases (Knovel), 2017.

${ }^{166}$ See http://trc.nist.gov/ for Thermodynamics Research Center, 2017.

${ }^{167}$ See https://cindasdata.com/products/tpmd Thermophysical Properties of Matter Database, 2017

${ }^{168}$ See http://oqmd.org/ for Open Quantum Materials Database.

${ }^{169}$ B. Wilthan, E. A. Pfeif, V. V. Dikya, R. D. Chiricoa, U. R. Kattner, and K. Kroenlein, CALPHAD 56, 126 (2017).

${ }^{170}$ T. N. Bhat, L. M. Bartolo, U. R. Kattner, C. E. Campbell, and J. T. Elliott, JOM 67(8), 1866-1875 (2015).

${ }^{171}$ See https://www.globus.org for Globus, 2016.

${ }^{172}$ See https://materialsdata.nist.gov for Material Measurement Laboratory Repository Server, 2013.

${ }^{173}$ See http://www.prisms-center.org for Prisms.

${ }^{174}$ B. Puchala, G. Tarcea, E. A. Marquis, M. Hedstrom, H. V. Jagadish, and J. E. Allison, J. Met. 68(8), 2035 (2016).

${ }^{175}$ See http://www.socrata.com for Socrata.

${ }^{176} \mathrm{See}$ http://www.citrine.io for Citrine Informatics.

${ }^{177}$ J. O'Mara, B. Meredig, and K. Michel, J. Met. 68(8), 2031 (2016).

${ }^{178}$ E. A. Pfeif and K. Kroenlein, APL Mater. 4(5), 053203 (2016).

${ }^{179}$ No approval or endorsement of any commercial product by NIST is intended or implied. Certain commercial software systems are identified in this paper to facilitate understanding. Such identification does not imply that these software systems are necessarily the best available for the purpose.

${ }^{180}$ See http://www.nist.gov/itl/ for NIST Information Technology Laboratory (ITL), 2016.

${ }^{181}$ See http://www.nist.gov/mml/ for NIST Material Measurement Laboratory (MML), 2016.

${ }^{182}$ See https://mgi.nist.gov/materials-resource-registry for NIST Materials Genome Initiative: Materials Resource Registry, 2015.

${ }^{183}$ A. Dima, S. Bhaskarla, C. Becker, M. Brady, C. Campbell, P. Dessauw, R. Hanisch, U. Kattner, K. Kroenlein, M. Newrock, A. Peskin, R. Plante, S.-Y. Li, P.-F. Rigodiat, G. Amaral, Z. Trautt, X. Schmitt, J. Warren, and S. Youssef, J. Met. 68(8), 2053 (2016).

${ }^{184}$ See https://mgi.nist.gov/materials-data-curation-system for Materials data Curation System, 2015.

185 ("virtual" in the same sense as the highly successful "Virtual Astronomical Observatory, http://www.usvao.org/about-vao/index.html).

${ }^{186} \mathrm{See} \quad \mathrm{http}$ ///energy.gov/eere/energy-materials-network/energy-materialsnetwork for Energy Materials Network, 2016.

${ }^{187}$ M. D. Jacobsen, J. R. Fourman, K. M. Porter, E. A. Wirrig, M. D. Benedict, B. J. Foster, and C. H. Ward, Integr. Mater. Manuf. Innovation $\mathbf{5}, 12$ (2016). 
${ }^{188}$ See http://t2c2.csl.illinois.edu/ for T2C2: Timely and Trusted Curation and Coordination, 2016.

${ }^{189}$ See https://www.handle.net/ for Handle.net Registry, 2016.

${ }^{190}$ See http://www.nacs.org/LinkClick.aspx?fileticket=D1FpVAvvJuo\%3D\&tabid= 1426\&mid=4802 for QR Code Essentials, 2011.

${ }^{191}$ R. S. Gates, M. J. McLean, and W. A. Osborn, J. Res. Natl. Inst. Stand. Technol. 120, 293-303 (2015).

${ }^{192}$ See https://materialsdatafacility.org/ for Materials Data Facility, 2016.

${ }^{193}$ B. Blaiszik, K. Chard, J. Pruyne, R. Ananthakrishnan, S. Tuecke, and I. Foster, J. Met. 68(8), 2045 (2016).

${ }^{194}$ J. Berkowitz, in DEIXIS Magazine Annual (2013), pp. 20-26.

${ }^{195}$ T. Hastie, R. Tibshirani, and J. Friedman, The Elements of Statistical Learning: Data Mining, Inference, and Prediction, 2nd ed. (Springer, 2009).

${ }^{196}$ B. Liu, Synth. Lect. Hum. Lang. Technol. 5(1), 1-167 (2012).

${ }^{197}$ Z. D. Stephens, S. Y. Lee, F. Faghri, R. H. Campbell, C. X. Zhai, M. J. Efron, R. Iyer, M. C. Schatz, S. Sinha, and G. E. Robinson, PloS Biol. 13(7), e1002195 (2015).

${ }^{198}$ S. LaValle, E. Lesser, R. Shockley, M. S. Hopkins, and N. Kruschwitz, MIT Sloan Manage. Rev. 52(2), 21 (2011).

${ }^{199}$ S. R. Kalidindi and M. De Graef, in Annual Review of Materials Research, edited by D. R. Clarke (Annual Reviews, Palo Alto, CA, 2015), Vol. 45, pp. 171-193.

${ }^{200}$ R. LeSar, Stat. Anal. Data Min. 1, 372-374 (2009).

${ }^{201}$ T. Mueller, A. G. Kusne, and R. Ramprasad, Reviews in Computational Chemistry, A. L. Parrill and K. B. Lipkowitz, editors (Wiley, 2016), Vol. 29, p. 186.

${ }^{202}$ S. Curtarolo, D. Morgan, K. Persson, J. Rodgers, and G. Ceder, Phys. Rev. Lett. 91(13), 135503 (2003).

${ }^{203}$ G. Hautier, C. C. Fischer, A. Jain, T. Mueller, and G. Ceder, Chem. Mater. 22(12), 3762-3767 (2010).

${ }^{204}$ B. Meredig, A. Agrawal, S. Kirklin, J. E. Saal, J. W. Doak, A. Thompson, K. Zhang, A. Choudhary, and C. Wolverton, Phys. Rev. B 89(9), 094104 (2014).
${ }^{205}$ C. J. Long, J. Hattrick-Simpers, M. Murakami, R. C. Srivastava, I. Takeuchi, V. L. Karen, and X. Li, Rev. Sci. Instrum. 78(7), 072217 (2007).

${ }^{206}$ S. Ermon, R. Le Bras, S. K. Suram, J. M. Gregoire, C. P. Gomes, B. Selman, and R. B. van Dover, paper presented at the 29th International Conference on Artificial Intelligence, 2015.

${ }^{207}$ J. R. Hattrick-Simpers, J. M. Gregoire, and A. G. Kusne, APL Mater. 4(5), 053211 (2016).

${ }^{208}$ G. Pilania, C. C. Wang, X. Jiang, S. Rajasekaran, and R. Ramprasad, Sci. Rep. 3, 2810 (2013).

${ }^{209}$ S. Curtarolo, G. L. W. Hart, M. B. Nardelli, N. Mingo, S. Sanvito, and O. Levy, Nat. Mater. 12(3), 191-201 (2013).

${ }^{210}$ S. R. Kalidindi, S. R. Niezgoda, and A. A. Salem, JOM 63(4), 34-41 (2011).

${ }^{211}$ H. Zhao, M. L. Comer, and M. A. De Graef, paper presented at the International Conference on Image Processing (ICIP), 2014.

${ }^{212}$ A. P. Bartok, M. C. Payne, R. Kondor, and G. Csanyi, Phys. Rev. Lett. 104(13), 136403 (2010).

${ }^{213}$ J. Behler, Phys. Chem. Chem. Phys. 13(40), 17930-17955 (2011).

${ }^{214}$ T. Morawietz and J. Behler, J. Phys. Chem. A 117(32), 7356-7366 (2013).

${ }^{215}$ J. C. Snyder, M. Rupp, K. Hansen, K. R. Muller, and K. Burke, Phys. Rev. Lett. 108(25), 253002 (2012)

${ }^{216}$ A. G. Kusne, T. R. Gao, A. Mehta, L. Q. Ke, M. C. Nguyen, K. M. Ho, V. Antropov, C. Z. Wang, M. J. Kramer, C. Long, and I. Takeuchi, Sci. Rep. 4, 6367 (2014).

${ }^{217}$ M. C. Roco and W. S. Bainbridge, Converging technologies for improving human performance: Nanotechnology, biotechnology, information technology, and cognitive science (Dordrecht, Boston, 2003).

${ }^{218}$ E. M. Campo, paper presented at the MRS Spring Meeting 2013, San Francisco, CA, 2013.

${ }^{219}$ J. Strobel and A. v. Barneveld, Interdiscip. J. Probl.-Based Learn. 3(1), 44 (2009). 